\title{
Hair loss: A review of the role of food bioactive compounds
}

\author{
Grace Wei $^{1,2}$ and Danik Martirosyan ${ }^{1}$
}

${ }^{1}$ Functional Food Institute, 5050 Quorum Drive, Suite 700, \#338, Dallas, TX, 75254, USA

${ }^{2}$ Boston University School of Public Health, 715 Albany St, Boston, MA 02118, USA

Corresponding Author: Danik Martirosyan, PhD, 4659 Texas Str., Unit 15, San Diego, CA 92116, USA

Submission Date: April $9^{\text {th }}$, 2018. Acceptance Date: May $29^{\text {th }}, 2019$. Publication Date: May $30^{\text {st }}, 2019$.

Citation: Wei G., Martirosyan, D. Hair Loss: A Review of the Role of Food Bioactive Compounds. Bioactive Compounds in Health and Disease 2019; 2(5): 94-125. DOI: https://doi.org/10.31989/bchd.v2i5.610

\begin{abstract}
The impact that hair loss can have on an individual's psychological wellness, and subsequent quality of life, is widespread and long lasting. Current standard care for hair loss includes surgery and medications, ranging from over-the-counter treatments to corticosteroid injections and immunosuppressants. Unfortunately, these current treatments are either expensive, invasive, or have extremely negative side effects on patients utilizing these therapies. Recently, the role of vitamins, minerals, and foods with their associated bioactive compounds, have gained increasing recognition as a potential mean to address this issue. Some of these compounds have been shown to decrease the risk of specific forms of hair loss, particularly alopecia, a form of balding that results due from an autoimmune disorder. These include experimental studies using black raspberry extract and egg yolks as well as epidemiological studies using Mediterranean diets and various micronutrients. Other compounds have been shown to promote hair growth on a more general scale, including in vivo studies using rice bran extract and mouse models using red ginseng oil and Annurca apple polyphenols. This review identifies key hair growth promoting vitamins, minerals, and other food bioactive compounds, summarizing relevant mechanisms of action of these elucidated compounds. However, it is imperative that further research be done to delineate exact dosage of those compounds, to check if in that effective dosage they are not toxic, and to subsequently integrate these dietary modifications into clinical treatment recommendations for hair loss.
\end{abstract}

Keywords: Hair loss, alopecia, berry extract, Mediterranean diet, rice bran, ginseng, Annurca apple, Thuja orientalis, marine supplement, honey, egg yolk, functional foods, bioactive compounds

\section{INTRODUCTION}

Psychological wellness and overall quality of life is severely impacted in individuals suffering from hair loss. The resulting change in cosmetic appearance is associated with reduced self- 
confidence and self-esteem, poor self-image perceptions, and feelings of embarrassment and vulnerability $[1,2]$. These damaging impacts on the human psyche negatively affect one's ability to engage in social interactions and have been associated with increased risk of mental health conditions, such as depression and anxiety [3]. Studies have shown that patients experiencing hair loss report reduced quality of life and higher prevalence of clinical depressive symptoms compared to comparable populations who are not suffering from hair loss [2].

Importantly, nutrition has also been shown to play key roles in the risk of developing hair loss. Hair follicles, in particular, have high turnover rates and high metabolic activity requiring an ample supply of energy from nutrients [4]. For example, a primary component of hair is keratin, which relies on adequate protein intake to maintain sufficient levels in the body. Thus, individuals suffering from malnourishment, including conditions such as Kwashiorkor, have been found displaying higher rates of hair loss [5]. Malnourishment commonly results in deficiency in these key amino acids: histidine, leucine, valine, alanine, and cysteine; low levels of these protein building blocks have been found to be associated with individuals suffering from hair loss [6]. We have already illustrated how protein deficiencies are common in many hair loss conditions, but other nutrients such as fatty acids, vitamins, and minerals have important roles as well [6]. It is, thus, not surprising that a number of food ingredients have risen in popularity as a means to address various forms of hair loss.

Prior to delving into foods or food ingredients that have immense potential to address hair loss conditions, it is critical to first define what functional foods are. Functional foods describe food products containing bioactive compounds that exhibit positive health benefits for preventing, treating, and managing chronic diseases [7]. It is the bioactive compounds present in functional foods that are primarily responsible for their potency as a hair loss treatment strategy, often due to their natural antioxidants, antifungals, and anti-inflammatory agents healing properties [7]. Among other bioactive molecules, vitamins and minerals also contribute to treating abnormal hair growth pathologies, such as by addressing oxidative stress or by modulating immune responses [8].

Overall, the use of foods with different bioactive compounds to prevent and manage hair loss could provide many benefits over current treatment options. As a whole, they are more costeffective and produce less side effects. Despite being less specific compared to synthetic medications, functional foods are considered safe for consumption, addressing not only hair loss problems but also provide benefits for other health concerns as well. This review of the literature will identify, consolidate, and review key food ingredients, food bioactive compounds, vitamins, minerals, polyphenols, bioactive proteins, and other ingredients for their effectiveness and potential in addressing hair loss and promoting hair growth. Relevant mechanisms of action that have been elucidated for each nutraceutical will also be summarized. Finally, in addition to improving knowledge surrounding functional and healthy foods for managing hair loss, this review aims to inform current strategies for addressing hair loss and propose future directions for this field.

\section{PATHOPHYSIOLOGY and CLINICAL MANIFESTATIONS OF HAIR LOSS}

The life cycle of a hair follicle proceeds through three phases: anagen, catagen, and telogen. The anagen phase is the growth stage, catagen is the degeneration stage, and telogen is the resting stage. 
The hair matrix milieu during the anagen phase is known to be extremely sensitive to external impacts, including hormonal abnormalities, medication use, stress, and immunological changes [9]. At the same time as these 3 phases are occurring, hair follicles are described to proceed through 8 morphological stages during this period, heavily influenced by autocrine, paracrine, and endocrine signaling [10].

The primary mechanism through which hair loss occurs is via disruption of the aforementioned follicular cycling, i.e. perturbations of the anagen, catagen, and telogen phase cycling processes [9]. Extended telogen duration as well as delayed anagen onset and reduced duration are common molecular mechanisms observed in hair loss [10]. A second mechanism through which hair loss conditions can developed are abnormalities in molecular signaling during the morphological stages [10]. Finally, loss of epithelial stem cells is a third common mechanism behind the development of hair loss [10]. As a whole, triggers for these alterations in hair growth are a combination of inflammation, hormonal changes, genetics, and environmental impacts [10]. These manifest in the form of hair-related medical conditions, nutritional deficiencies, endocrine imbalances, drug-related side effects, bacterial and viral infections, and certain diseases include various forms of cancer [1].

In general, the functional foods to be analyzed in this review article focus on treating and managing hair loss caused by hair-related medical conditions. The most common hair-related medical conditions will be briefly discussed. Hair loss caused by hair-related medical conditions take two forms, namely, diffuse and focal hair loss, which is further divided into subsets of hair loss conditions [15]. The most common condition that causes hair loss is hereditary hair loss [110]. Other common hair loss conditions include male or female pattern hair loss (MPHL or FPHL, respectively). MPHL, often denoted as androgenetic alopecia, is the most common root cause of baldness in men, with FPHL similarly being the most common root cause for women. Study estimates show that the prevalence of pattern baldness can be as high as $70 \%$ in men and as high as $40 \%$ in women $[16,17,18,19]$, depending on the study being reviewed. Androgenetic alopecia, whether occurring in males as MPHL or in females as FPHL, is believed to result from androgen imbalance in genetically susceptible individuals $[16,17,18]$. Other common forms of hair loss include Alopecia areata and Telogen effluvium [16]. Alopecia areata is an autoimmune disorder that often results in patch-like losses of hair on the scalp and body [11,12]. Alopecia areata is the most common cause of hair loss in adolescents [20]. Unlike, Alopecia areata, telogen effluvium is not thought to have underlying genetic predispositions, but rather is caused by a myriad of physiological and psychological stressors, including malnutrition, chronic illness, and certain medications [11, 12]. Telogen effluvium results in the specific loss of telogen hair, due to abnormal follicular cycling in the anagen, catagen, and telogen phases of hair growth [16].

Common symptoms for hair loss include abrupt or gradual onset of hair loss, patchy or diffuse hair loss, and thinning. A physical examination and patient history are then performed to differentially diagnose the form of hair loss in the suffering patients. This includes determining if the hair loss is localized or systemic, family history or medication use, hair pull tests, and presence of scarring $[11,12]$. Although, there are generally no routine tests available to diagnose hair loss, laboratory testing or histological examination are often conducted to determine any underlying endocrine abnormalities and structural damages to hair including hair breakings $[11,12,13]$. For example, levels of testosterone, dehydroepiandrosterone (DHEA), iron, iron-binding capacity, and 
thyroid hormones are commonly used to identify underlying causes of hair loss, particularly in premenopausal women [14].

Current treatment methods for hair loss vary depending on the specific condition, however, most strategies consist of medications (synthetic therapeutics), surgeries, and the recent development of low-level light therapies. Corticosteroids and immunosuppressive agents are often used, however, their negative side effects make them less than ideal choices [21]. These include topical, oral, and intralesional steroids, topical minoxidil, and topical immunotherapies [15]. Hair transplant surgeries have displayed impressive hair graft survival rates, with clinical study success rates ranging from $90 \%$ to $100 \%$ [22]. In reality, however, under non-experimental conditions, graft survival rates in common clinical practice often fall below $100 \%$, due to issues including donor scalp issues, operative-related graft damage [22]. The advent of low-level light therapies, approved by the FDA in 2007 to treat hair loss, has been touted to be safe but its' effectiveness has still yet to be confirmed [16].

\section{RETRIEVAL OF PUBLISHED STUDIES}

A systematic review of published literature on food ingredients related to hair growth was conducted via electronic searches on PubMed, Google Scholar, and Web of Science databases. Articles not available in English were excluded, but no other limitations were imposed. Both review and primary research articles were included. Eligible articles provided relevant scientific evidence on hair growth benefits of any food item. Keywords for the searches included: anagen, Annurca apple, apple, alopecia, baldness, berry, bioactive compounds, catagen, dermal, dermal papilla, egg, epidermal, female pattern hair loss, follicular, functional foods, ginseng, hair growth, hair loss, health, honey, keratinocyte, male pattern hair loss, marine supplements, Mediterranean diet, physiological, prevention, psychological, rice bran, risk, supplement, symptoms, telogen, Thuja orientalis, and treatment.

\section{BERRY EXTRACT}

\section{Berry Fruits as a Candidate Functional Food}

Berry fruits, particularly blackberries and raspberries, have long been known for their nutritive and medicinal benefits. They are high in dietary fiber and contain important micronutrients, including Vitamin C, Vitamin K, and essential minerals, copper, and manganese [23]. In addition to being nutritionally rich, berries also contain high levels of phytochemicals and bioactive compounds, including steroids, glycosides, terpenes, and acids [24]. Beyond these, they are known for their abundance of phenolic compounds, notably anthocyanins, flavonols, and tannins, as seen in Figure 1 [25]. These phenolic compounds are especially important for the medicinal benefits berries provide, contributing antioxidant, anti-inflammatory, and anticancer properties [26]. Blackberries, in the form of pulp formulations, have shown high cytotoxic effects against MCF-7 and SKBR3 breast cancer cell lines [26]. While oral consumption and subsequent digestion of blackberries will likely alter these anti-carcinogenic properties in vivo, the positive health benefits they display beyond basic nutritive needs are still medicinally beneficial. Sources show blackberries have antiaging benefits, including protection against neurological decline and bone loss that occur during the aging process [25]. Traditionally, berries have also often been used in herbal medicine as antimicrobial, antidiarrheal, antidiabetic, and antiviral agents [23, 24]. 
Anthocyanins are one of the most well-known bioactive compounds present in berries. Anthocyanins, the glycosidic form of anthocyanidins, are water-soluble pigments responsible for the vibrant colors of fruits and vegetables [27]. They fall under the category of flavonoids, which further falls under the greater category of polyphenols [28]. Blackberries are particularly high in anthocyanin content, with an estimated nearly $66 \mathrm{mg}$ of anthocyanin per 100 grams of fruit, compared to $30 \mathrm{mg}$ of anthocyanin per 100 grams of fruit in raspberries [29]. Importantly, bioavailability studies have shown that anthocyanins are uniquely absorbed intact, in their glycosidic form [30, 31]. Unfortunately, the overall bioavailability of anthocyanins in human studies have been shown to be consistently low $[32,33]$. Despite this, anthocyanins have still been shown to have significant positive effects on human health, including as an antioxidant and protecting against vision degeneration, obesity, diabetes, and cancer [28]. As an antioxidant, anthocyanins are potent free radical scavengers and inhibitors of lipid oxidation, including inhibition of human low-density lipoprotein (LDL) [34]. Anthocyanin extracts produced from berries have been used in numerous studies and have been shown to improve night vision both in animal and human studies [35]. In regards to obesity and diabetes, anthocyanins are protective not only in antioxidative benefits, but also an insulin secretagogue [36]. It is thought that anthocyanins have anti-proliferative and pro-apoptotic effects, in addition to antioxidant effects, that contribute to their anti-carcinogenic functionality [28].<smiles>Oc1cc(O)c2cc(O)c(-c3ccc(O)c(O)c3)[o+]c2c1</smiles>

Cyanidin<smiles></smiles>

Petunidin<smiles>COc1cc(-c2[o+]c3cc(O)cc(O)c3cc2O)cc(OC)c1O</smiles>

Malvidin<smiles>Oc1ccc(-c2[o+]c3cc(O)cc(O)c3cc2O)cc1</smiles>

Pelargonidin<smiles></smiles>

Delphinidin<smiles>COc1cc(O)c2cc(O)c(-c3ccc(O)c(OC)c3)[o+]c2c1</smiles>

Rosinidin

Figure 1. Chemical structures of major bioactive compounds present in berries.

\section{Functionality of Berry Fruits in Treating Hair Loss}

Recent research has provided evidence that berries may serve as potent natural treatments for hair loss, as seen in Table 1 [37, 38, 40]. Firstly, the hair promoting benefits of berry fruits have been described jointly with anti-aging effects. Dan et al. studied hair loss as it relates to anti-aging properties by applying four different berry formulations (black raspberry, blueberry, raspberry, and blabina, a powered black raspberry extract) to cell culture [37]. They found all four formulations increased hair growth via increasing growth of dermal follicular cells by up to $20 \%$ 
and promoting expression of type 17 collagen and heat shock protein 47 (HSP47) mRNA in follicular stem cells [37]. Expression of type 17 collagen and HSP47 are key, as hair loss can be associated with reduced levels of the type 17 collagen protein or HSP47, an inhibitor of type 17 collagen proteolysis [37]. Thus, increased levels of either of these proteins is thought to reverse the effects of hair loss. Importantly, Dan et al. also found that all four formulations increased hair growth via inhibition of the enzyme, 5-alpha-reductase, in dermal follicular cells [37]. This enzyme, 5-alpha-reductase, is responsible for converting testosterone into dihydrotestosterone (DHT). Because high levels of DHT have been found to be associated with hair loss, inhibition of 5-alpha-reductase has become a prime target for hair growth therapies, and incorporation of berries or berry-based formulations to target this enzyme may be a strong option.

Secondly, the hair promoting benefits of berries have also been shown to occur through activation of sensory neurons, through a similar mechanism as capsaicin, a compound found in chili peppers. Topical capsaicin activates sensory neurons, causing the release of calcitonin-gene related peptide (CGRP), and subsequent release of insulin-like growth factor-1 (IGF-1) in the dermis [38,39]. IGF-1 is known to play a role in the follicular hair growth cycle and has been shown to promote maturation of hair follicles. Raspberries contain an aromatic compound known as raspberry ketone (RK), which is similar in structure to capsaicin. Because of their structural similarities, Harada et al. tested the ability of raspberry ketone to comparably activate sensory neurons, causing release of CGRP and IGF-1, and subsequent hair growth [40]. They found that topical application of raspberry ketone resulted in increased levels of CGRP release from sensory neurons, increased IGF-1 in the dermis, and increased hair growth in wild-type mice [40]. Importantly, topical application of raspberry ketone did not result in increased IGF-1 in the dermis of CGRP knockout mice, indicating that the molecular mechanism of raspberry ketone-induced hair growth is mediated through CGRP [40]. Finally, Harada et al. found that topical application of raspberry ketone resulted in improved hair growth in 50\% of alopecia study participants [40].

Third, the ability of berries to promote hair growth has been mechanistically linked to the JAK-STAT signaling pathway. Certain forms of hair loss have been associated with an inability of follicular cells to proceed from the telogen (resting phase) to the anagen (growth phase) of the hair growth cycle. A study by Harel et al. showed that inhibition of the JAK-STAT pathway, using a topical inhibitor, promoted rapid entry from telogen to anagen [41]. This rapid entry showed similar kinetics to those promoted by sonic hedgehog (Shh) agonists, which is a pathway known to promote initiation of the anagen hair growth phase [41]. A later study conducted by Martin et al in the same year identified numerous bioactive compounds capable of inhibiting JAK, including blackberries, boysenberries, and strawberries [42]. The potency of the JAK inhibition by these berries was thought to be due to the presence of high levels of ellagitannins, a subset of tannins known to inhibit kinases [42]. It is thus highly probable that berries containing high levels of ellagitannins are capable of inhibiting JAK and inducing hair growth. Collectively, these studies suggest that incorporating berries or berry extracts into diets or topical formulations for individuals suffering from a hair loss condition may be a potent natural alternative or complement to drugbased treatment strategies. 
Table 1. Summary of Research on Berry-based Hair Growth Studies

\begin{tabular}{|c|c|c|c|c|c|}
\hline Study & $\begin{array}{l}\text { Type of } \\
\text { Study }\end{array}$ & $\begin{array}{l}\text { Intervention and/or } \\
\text { Bioactive Ingredients }\end{array}$ & $\begin{array}{c}\text { Dosage and } \\
\text { Administration Time }\end{array}$ & Outcome & Impact \\
\hline \multirow[t]{4}{*}{$\begin{array}{l}\text { Harada et } \\
\text { al., 2008 } \\
{[40]}\end{array}$} & In vitro & $\begin{array}{l}\text { In vitro: } 99.9 \% \text { pure } \\
\text { raspberry ketone (RK) } \\
\text { on DRG cells }\end{array}$ & $\begin{array}{l}\text { In vitro: } 1,10, \text { and } 100 \\
\mu \mathrm{M} \text { RK at } 30 \text { min. } \\
\text { incubation period }\end{array}$ & $\begin{array}{l}\text { Increased CGRP release } \\
\text { from DRG cells; }\end{array}$ & $\begin{array}{l}\text { RK increases hair } \\
\text { growth via upregulating } \\
\text { IGF-1 secretion in a } \\
\text { CGRP-dependent } \\
\text { manner. }\end{array}$ \\
\hline & $\begin{array}{l}\text { In vivo } \\
\text { (C57BL/6) } \\
\text { mouse }\end{array}$ & $\begin{array}{l}\text { In vivo: Topical RK on } \\
\text { WT or CGRP-KO mice }\end{array}$ & $\begin{array}{c}\text { In vivo: Topical } 100 \mu \mathrm{L} \\
\text { of } 0.01 \% \text { RK for } 30 \\
\text { minutes, also } 1 / \text { day for } \\
4 \text { weeks }\end{array}$ & $\begin{array}{l}\text { Increased IGF-1 and hair } \\
\text { growth in WT mice, }\end{array}$ & \\
\hline & $\begin{array}{c}\text { Clinical } \\
\text { experiment } \\
\text { (part 1) }\end{array}$ & $\begin{array}{c}\text { Clinical trial 1: } \\
\text { Topical RK to } 10 \\
\text { alopecia ( } 7 \text { males and } 3 \\
\text { females) volunteers (all } \\
\text { receive treatment) }\end{array}$ & $\begin{array}{c}\text { Clinical trial 1: } \\
\text { Alopecia volunteers } \\
\text { (0.01\% RK 1/night for } 5 \\
\text { months) }\end{array}$ & $\begin{array}{c}\text { Increased hair growth in } \\
50 \% \text { of volunteers at } 5 \\
\text { months }\end{array}$ & \\
\hline & $\begin{array}{l}\text { Clinical } \\
\text { experiment } \\
\text { (part 2) }\end{array}$ & $\begin{array}{c}\text { Clinical trial 2: } \\
\text { Topical RK to } 10 \text { healthy } \\
\text { female volunteers ( } 5 \\
\text { treatment, } 5 \text { control) }\end{array}$ & $\begin{array}{c}\text { Clinical trial 2: } \\
\text { Healthy female } \\
\text { volunteers ( } 0.01 \% \text { RK } \\
1 / \text { day for } 2 \text { weeks) }\end{array}$ & $\begin{array}{c}\text { Increased cheek skin } \\
\text { elasticity }\end{array}$ & \\
\hline $\begin{array}{l}\text { Harel et } \\
\text { al., } 2015 \\
\text { [41] }\end{array}$ & $\begin{array}{l}\text { In vivo } \\
\text { (C57BL/6) } \\
\text { mouse } \\
\text { model }\end{array}$ & $\begin{array}{l}\text { Small-molecule } \\
\text { inhibitors of the JAK- } \\
\text { STAT pathway, e.g. } \\
\text { tofacitinib and } \\
\text { ruxolitinib }\end{array}$ & $\begin{array}{c}\text { 2-3\% JAK-STAT } \\
\text { inhibitor dissolved in } \\
\text { DMSO 1/day for } 4 \\
\text { days, with biopsies } \\
\text { taken on Day } 0 \text { and } 5 .\end{array}$ & $\begin{array}{l}\text { Rapid entry into anagen } \\
\text { phase, increased } \\
\text { proliferation of follicular } \\
\text { stem cells. }\end{array}$ & $\begin{array}{l}\text { Inhibition of JAK-STAT } \\
\text { signal transduction } \\
\text { upregulates hair } \\
\text { growth pathways. }\end{array}$ \\
\hline $\begin{array}{l}\text { Martin et } \\
\text { al., 2015 } \\
\text { [42] }\end{array}$ & $\begin{array}{l}\text { In vitro cell } \\
\text { culture }\end{array}$ & $\begin{array}{c}49 \text { different food } \\
\text { extracts, including } 10 \\
\text { concentrated } \\
\text { hydrophobic fractions of } \\
\text { each, to find JAK2 } \\
\text { inhibitors. }\end{array}$ & $\begin{array}{l}10 \text { fractions for each of } \\
\text { the } 49 \text { extracts, } \\
\text { ranging from } 10^{1} \text { to } \\
10^{7} \text {-fold dilutions. }\end{array}$ & $\begin{array}{l}\text { Blackberry, boysenberry, } \\
\text { and strawberry were } \\
\text { observed to potently } \\
\text { inhibit JAK2. }\end{array}$ & $\begin{array}{l}\text { Berries may be capable } \\
\text { of promoting hair } \\
\text { growth via inhibition of } \\
\text { JAK pathways. }\end{array}$ \\
\hline $\begin{array}{l}\text { Dan et al., } \\
2018 \text { [37] }\end{array}$ & $\begin{array}{l}\text { In vitro cell } \\
\text { culture }\end{array}$ & $\begin{array}{c}\text { Blackberry extract } \\
\text { (BRE), blueberry extract } \\
\text { (BBE), raspberry extract } \\
\text { (RBE), Blabina } \\
\text { (powdered formulation } \\
\text { containing BRE) }\end{array}$ & $\begin{array}{l}10^{1} \text { to } 10^{\text {s-fold dilutions }} \\
\text { of } 9 \mathrm{mg} / \mathrm{ml} \text { with } \\
\text { incubation ranging } \\
\text { from } 1 \text { hour to } 48 \\
\text { hours }\end{array}$ & $\begin{array}{c}\text { Blabina \& BRE: } \\
\text { Upregulation of } \alpha- \\
\text { crystallin, inhibited } 5 \alpha- \\
\text { reductase } \\
\text { Blabina, BRE, BBE, RBE: } \\
\text { Increased dermal papilla } \\
\text { growth. }\end{array}$ & $\begin{array}{c}\text { Berry extracts, } \\
\text { particularly blackberry } \\
\text { extract, have potent } \\
\text { anti-aging properties, } \\
\text { including promoting } \\
\text { hair growth. }\end{array}$ \\
\hline
\end{tabular}

In summary, in vivo and in vitro studies, and one clinical experiment was conducted to test the hair growth potential of berries. The study by Harada et al., was a strong collection of in vivo, in vitro, and clinical investigation that detailed the mechanism of action of berry bioactive compounds, however, the number of participants in the clinical component of the study was very limited [40]. The remaining in vivo and in vitro studies showed promising results, however, these studies did not directly show the impact of berry bioactive compounds on hair growth. Harel et al. and Martin et al. provided a mechanism through which berries may increase hair growth through inhibition of JAK-STAT, while Dan et al. did clearly use berry-based bioactive compounds, but showed increased dermal papillae growth [37, 41, 42]. While this is not a direct observation of increased hair growth, increased dermal papillae growth is expected to increase hair growth. Importantly, another limitation is none of these studies looked at toxicity dosing. 


\section{The Functionality of the Mediterranean Diet}

The Mediterranean diet is a dietary pattern growing in popularity as a means of preventing, treating, and managing a variety of health conditions. The Mediterranean diet mainly consists of one cup of daily red wine, with high consumption of fruits, vegetables, and virgin olive oil, and low consumption of fish and meat [43]. Virgin olive oil is a staple of the Mediterranean diet, due to its high content of bioactive phenolic compounds [44]. Red wine and tomatoes are also of key importance, due to their high levels of resveratrol and lycopene, respectively [45]. The combination of resveratrol, phenolic compounds, and lycopene in the Mediterranean diet have been associated with decreased risk of colorectal cancer [45]. Furthermore, epidemiological observation has shown decreased prevalence and incidence of chronic conditions, including cardiovascular disease and subsequent risk of stroke, myocardial infarction, and so on, in addition to, cancer, metabolic syndrome and diabetes, and cognitive neurodecline [46], in those adhering to Mediterranean diets. Experimental intervention studies have further supported these findings, illustrating that Mediterranean diets result in decreased risk of cardiovascular disease, metabolic syndrome and diabetes, and cognitive neurodecline, in treatment groups assigned to Mediterranean diets [46].

\section{Functionality of Mediterranean Dietary Ingredients in Treating Hair Loss}

Research on the role of the Mediterranean diet in treatment of hair loss remains relatively limited, however, a few key components of the Mediterranean diet have proven promising in the addressing hair loss (Table 2) [47, 48, 49]. One recent case-control study by Fortes et al. showed that individuals who followed a Mediterranean diet with high vegetable and herb intake had about a $56-57 \%$ reduced odds of developing androgenetic alopecia [47]. While androgenetic alopecia has been known to stem mainly from genetic factors, this study demonstrated that androgenetic alopecia may be heavily impacted by diet as an environmental factor.

Additionally, an important ingredient in Mediterranean diets are tomatoes, vegetables rich in lycopene. Research has shown that Lycopersicon esculentum extracts have potent abilities to promote hair growth in a C57BL/6 murine model [48]. This increase in hair growth was observed both histologically and via gene expression, with Lycopersicon esculentum extracts application resulting in increased vascular endothelial growth factor, keratinocyte growth factor, and insulinlike growth factor [48]. Increased expression of these growth factors and subsequent action of hair follicles is suggested to be one of the main mechanisms through which lycopene induces hair growth [48]. Another integral component of the Mediterranean diet, red oranges have been shown to also have beneficial effects on keratinocyte populations within the epidermis. Cardile et al. showed that treatment with red orange extract resulted in decreased inflammatory activity, measured via inflammatory markers, in human keratinocyte cell lines [49]. This is key as it enhances hair growth by creating a cellular milieu favoring keratin production, the main component of hair. The implementation of Mediterranean diets or components of Mediterranean diets, such as lycopene-rich ingredients, are strong options for those interested in incorporating natural therapeutics into hair growth regimens. 
Table 2. Summary of Research on Mediterranean diet-based Hair Growth Studies

\begin{tabular}{|c|c|c|c|c|}
\hline Study & Type of Study & $\begin{array}{l}\text { Intervention and/or } \\
\text { Bioactive Ingredients }\end{array}$ & $\begin{array}{l}\text { Dosage and Administration } \\
\text { Time }\end{array}$ & Outcome \\
\hline $\begin{array}{l}\text { Cardile et } \\
\text { al., } 2009 \\
\text { [49] }\end{array}$ & $\begin{array}{l}\text { In vitro cell } \\
\text { line (human } \\
\text { keratinocyte) }\end{array}$ & $\begin{array}{l}\text { Red orange complex } \\
\text { from Moro, Tarocco, } \\
\text { Sanguinello citrus } \\
\text { fruits }\end{array}$ & $\begin{array}{l}10 \text { and } 100 \mu \mathrm{g} / \mathrm{mL} \text { red orange } \\
\text { complex at } 48 \text { hour incubation }\end{array}$ & $\begin{array}{l}\text { Downregulated ICAM-1 } \\
\text { expression and MCP-1 and IL-8 } \\
\text { release. }\end{array}$ \\
\hline $\begin{array}{c}\text { Choi et al., } \\
2013 \text { [48] }\end{array}$ & $\begin{array}{c}\text { In vivo } \\
\text { (C57BL/6) } \\
\text { mouse model }\end{array}$ & $\begin{array}{c}\text { Lycopersicon } \\
\text { esculentum extracts }\end{array}$ & $\begin{array}{l}\text { 3\% ethyl acetate extract (EAE), } \\
\text { supercritical CO2 extract (SCE) } \\
\text { of L. esculentum, lycopene } \\
\text { Tween } 80 \text { solution (LTS), and } \\
\text { test hair tonic (THT) containing } \\
\text { LTS } 1 \text { day for } 4 \text { weeks }\end{array}$ & $\begin{array}{l}\text { Increased hair growth and } \\
\text { anagen phase induction; } \\
\text { increased expression of VEGF, } \\
\text { KGF, and IGF-1. }\end{array}$ \\
\hline $\begin{array}{l}\text { Fortes et al., } \\
2018 \text { [47] }\end{array}$ & $\begin{array}{c}\text { Hospital- } \\
\text { based case- } \\
\text { control study } \\
\text { (104 alopecia } \\
\text { cases and } 108 \\
\text { controls) }\end{array}$ & $\begin{array}{l}\text { No intervention, } \\
\text { exposure was } \\
\text { categorized as } \\
\text { frequency of } \\
\text { consumption of } \\
\text { Mediterranean diet- } \\
\text { based components. }\end{array}$ & $\begin{array}{c}\text { No dosage or time } \\
\text { administration due to case- } \\
\text { control study design. Frequency } \\
\text { of consumption was considered } \\
\text { high ( } \geq 3 \text { times/week) or low } \\
\text { (up to } 2 \text { times/week) for a } \\
\text { variety of Mediterranean diet } \\
\text { items, including: cooked, raw, } \\
\text { leafy green, and cruciferous } \\
\text { vegetables, herbs, fruits, nuts, } \\
\text { olive, oil, etc. }\end{array}$ & $\begin{array}{c}\text { Adjusted OR*: } \\
\text { High vs. low raw vegetable } \\
\text { consumption: } 0.43^{* * *} \\
\text { High vs. low fresh herb } \\
\text { consumption: } 0.44 * * \\
\text { *Adjusted for age, education, } \\
\text { BMI and family history of AGA. } \\
* * * p<0.05\end{array}$ \\
\hline
\end{tabular}

Overall, the in vitro and in vivo studies demonstrated potential mechanisms of Mediterranean diet based bioactive compounds on increasing hair growth through modulating expression of growth factors, cytokines, and cell mediators [48, 49]. The inclusion of a case-control study provides a unique epidemiological perspective demonstrating plausible association between Mediterranean-diet and hair growth, however, potential bias and confounding should be taken into consideration [47]. While the results of these studies are encouraging, unfortunately, the impact of Mediterranean diet based bioactive compounds on hair growth are limited by a lack of clinical experiments and consistency in dosing regimens.

\section{RICE BRAN EXTRACT}

\section{Rice Bran as a Candidate Functional Food}

Rice has served as a staple component of dietary lifestyles across the world for centuries. The production of rice results in removal of a protective husk under which lies the rice bran, the innermost rice kernel. Rice bran has been found to contain high amounts of macronutrients, including dietary fiber, proteins, and lipids [50]. Bioactive compounds present in rice bran are also extensive, most notably antioxidants, including ubiquinones, tocopherols, tocotrienols, and yoryzanol $[50,52]$. In addition to antioxidant activity, rice bran-derived nutraceuticals display antiinflammatory, anti-diabetic, and anti-cancer characteristics [53]. In particular, tocotrienols have 
been shown to inhibit HMG-COA Reductase and contribute to lowering endogenous cholesterol production [52].

\section{Functionality of Rice Bran in Treating Hair Loss}

A few studies within the past decade have shown the natural therapeutic potential of rice bran for treating various forms of hair loss, as summarized in Table 3 [54, 55, 58]. Manosroi et al., demonstrated the potential application of rice bran-based niosomes as a topical therapeutic for androgenic alopecia [54]. The depth of dermal penetration by topical medicines in treating hair loss is an important component of their efficacy. Manosroi et al. have shown that components of rice bran Oryza sativa, particularly unsaturated fatty acids, are potent inhibitors of 5a-reductase and thus work to inhibit hair loss [54]. Despite this, these researchers discovered that the depth of penetration by components of the Oryza sativa was limited. In this study, they developed a topical gel containing Oryza sativa rice bran components packaged into cationic niosomes [54]. Using an in vitro analysis of porcine skin, Manosroi et al. found greater penetration through topical gel when compared to control delivery methods [54]. Importantly, they also found the penetration did not extend into the receiver compartment, analogous to beyond the dermal layer, indicating high dermal effects but low systemic effects of the rice bran gel preparation [54].

Further, Choi et al. tested the in vivo ability of rice bran to promote hair growth by applying rice bran extracted using supercritical carbon dioxide (RB-SCE) to shaved C57BL/6 mice in the telogen phase of the follicular cycle [55]. Histological examinations showed higher rates of hair restoration and induction into anagen phase occurred in mice treated with RB-SCE, compared to controls [55]. RB-SCE-treated mice showed similar histological growth profiles to minoxidiltreated controls; minoxidil is a topical agent currently approved by the FDA to treat androgenetic alopecia [55]. These researchers also found that application of the rice bran extract induced mRNA expression of a number of growth factors related to hair growth. In particular, mice treated with RB-SCE showed increased MRNA expression of vascular endothelial growth factor (VEGF), insulin-like growth factor-1 (IGF-1), and keratinocyte growth factor (KGF), as well as decreased mRNA expression of TGF-b [55]. This particular pattern of expression has been shown to play a role in increasing the maintenance of the anagen phase of hair growth [56, 57].

Choi et al. also tested the ability of supercritical carbon dioxide extracted-rice bran to treat androgenic alopecia in a clinical trial [58]. During a double-blind randomized control trial performed over 16 weeks, 25 participants received topical RB-SCE treatment $(0.5 \%$ RB-SCE or 8 $\mathrm{mL} / \mathrm{d}$ ) while the control group of 25 participants received a placebo [58]. Their results showed statistically significant increases in total hair count, hair diameter, and overall hair density in male patients receiving the RB-SCE treatment [58]. Importantly, increases were observed in female patients as well, however these were not statistically significant [58]. This suggests potential differences in the physiological effects of the RB-SCE treatment between biological sex characteristics. Additionally, Choi et al. found a positive improvement in patient satisfaction with the RB-SCE treatment and the impact it had on their hair growth and scalp appearance [58]. This study suggests high potential for rice bran extracts to be used as natural therapeutic treatments for hair loss, particularly in males. As a whole, these studies support the recommendation of including rice bran into dietary patterns to prevent or treat hair loss. 
Table 3. Summary of Research on Rice Bran-based Hair Growth Studies

\begin{tabular}{|c|c|c|c|c|}
\hline Study & Type of Study & $\begin{array}{l}\text { Intervention and/or } \\
\text { Bioactive Ingredients }\end{array}$ & $\begin{array}{c}\text { Dosage and } \\
\text { Administration Time }\end{array}$ & Outcome \\
\hline $\begin{array}{c}\text { Manosroi } \\
\text { et al., } 2012 \\
{[54]}\end{array}$ & $\begin{array}{l}\text { In vitro } \\
\text { transfollicular } \\
\text { penetration of } \\
\text { porcine skin }\end{array}$ & $\begin{array}{l}\text { Cationic niosomes } \\
\text { containing Oryza } \\
\text { sativa rice bran. }\end{array}$ & $\begin{array}{l}48.23 \%(\mathrm{w} / \mathrm{w}) \text { or } 2 \%(\mathrm{w} / \mathrm{v}) \\
\text { O. sativa extracts loaded } \\
\text { into } 20 \mathrm{mM} \text { niosomes at } \\
1: 1: 0.5 \mathrm{M} \text { ratio }\end{array}$ & $\begin{array}{l}\text { Rice bran based-niosomes } \\
\text { exhibited } 8 \text { times greater skin } \\
\text { penetration compared to rice } \\
\text { bran-based gel and } 6 \text { times } \\
\text { greater compared to a rice-bran } \\
\text { based solution. }\end{array}$ \\
\hline $\begin{array}{l}\text { Choi et al., } \\
2014 \text { [55] }\end{array}$ & $\begin{array}{c}\text { In vivo }(\mathrm{C} 57 \mathrm{BL} / 6) \\
\text { mouse model }\end{array}$ & $\begin{array}{c}\text { Rice bran } \\
\text { supercritical CO2 } \\
\text { extract (RB-SCE) }\end{array}$ & $\begin{array}{c}100 \mu \mathrm{L} 3 \% \text { in } 10 \% \text { ethanol } \\
\text { RB-SCE topical } 1 / \text { day for } 4 \\
\text { weeks }\end{array}$ & $\begin{array}{l}\text { Increased hair follicle count, } \\
\text { anagen phase induction, and } \\
\text { expression of VEGF, KGF, and IGF- } \\
\text { 1. Decreased TGF-b expression. }\end{array}$ \\
\hline $\begin{array}{l}\text { Choi et al., } \\
2015 \text { [58] }\end{array}$ & $\begin{array}{l}\text { Double-Blind } \\
\text { Randomized } \\
\text { Controlled Trial } \\
\text { of } 28 \text { men and } \\
22 \text { women }\end{array}$ & $\begin{array}{l}\text { Rice bran } \\
\text { supercritical CO2 } \\
\text { extract (RB-SCE) or } \\
\text { placebo treatment }\end{array}$ & $\begin{array}{l}0.5 \% \text { RB-SCE or placebo } 4 \\
\mathrm{~mL} \text { twice/day at } 12 \text {-hour } \\
\text { intervals (total } 8 \mathrm{~mL} / \text { day) } \\
\quad \text { for } 16 \text { weeks }\end{array}$ & $\begin{array}{l}\text { Increased total hair count, hair } \\
\text { diameter, and overall hair density } \\
\text { in male patients, not significant in } \\
\text { female patients. }\end{array}$ \\
\hline
\end{tabular}

A series of pre-clinical tests followed by a clinical trial provide strong support for a causal association between rice and bran and hair growth $[54,55,58]$. However, these studies are limited by lack of consistency in dosing and a small sample size in the clinical trial. Because of the lack of significance observed in women, controlling for sex in future studies will be important. Additionally, although the mouse model provides a potential mechanism of action for the observed increase in hair growth by rice bran, the specific rice bran bioactive molecule responsible for this effect still remains unclear.

\section{GINSENG}

\section{Ginseng as a Candidate Functional Food}

Ginseng is a plant belonging to the Panax genus commonly used in traditional herbal medicines [59]. The primary bioactive components of ginseng are saponins, specifically ginsenosides, with the chemical structure of steroid glycosides, seen in Figure 2[60]. Ginsenosides have been shown to have numerous beneficial effects on physiological functioning, including anti-oxidative, antiinflammatory, anti-fatigue, anti-cancer, anti-diabetic, anti-obesity, anti-microbial and protective effects on the respiratory, cardiovascular, neurologic, and immune systems [60]. Importantly, nonsaponin components of ginseng, including polyacetylenes, polyphenols, and vitamins and minerals, have also been shown to have potent medicinal properties as well [59]. In a 2016 study by Kim et al. studying the non-saponin contents of ginseng, it was found that the ginseng leaves contained the highest levels of phenolic compounds, which have been described to have potent antioxidant activities [59]. Kim also showed that the ginseng root hairs contained high levels of water-soluble vitamins, particularly thiamine, and pantothenic acid, with average total watersoluble vitamin contents at nearly $800 \mathrm{mg} / 100 \mathrm{~g}$ of dry ginseng [59]. 


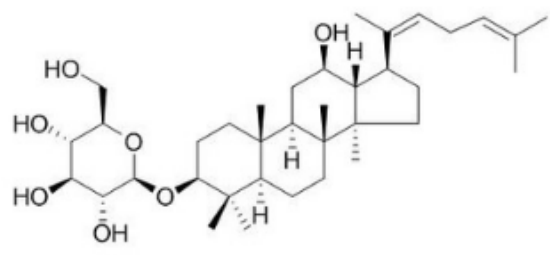

Ginsenoside Rh3

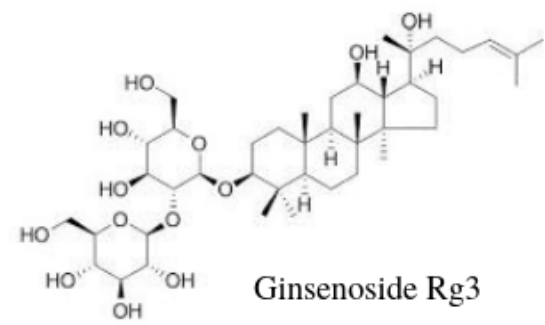

Protopanaxadiols
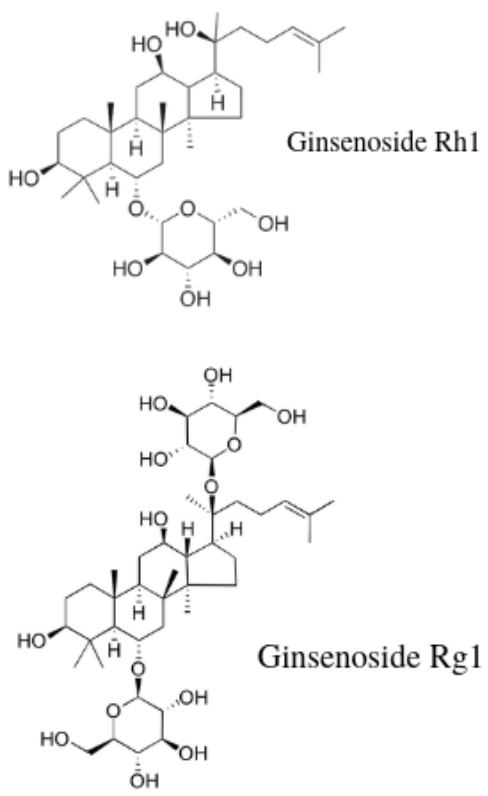

Protopanaxatriols

Figure 2. Chemical structures of major ginsenosides present in ginseng.

\section{Functionality of Red Ginseng Oil in Treating Hair Loss}

The efficacy of using ginseng to treat various forms of hair loss has been extensively documented in the literature, in both pre-clinical and clinical studies. Table 4 displays a number of in vitro experiments that have documented protective effects of ginseng on epidermal components and promotion of hair growth [61, 62, 64, 71, 72, 73]. Park et al. demonstrated the ability of Fructus panax ginseng extract to increase hair growth by targeting human dermal papilla cells (DPCs) and increase their proliferation in a C57BL6 murine model, resulting in visible hair regeneration in the treatment group compared to the control [61]. Researchers also showed that Fructus panax ginseng extract was able to increase BCL-2 and decrease BAX expression, anti-apoptotic and pro-apoptotic mediators, respectively, thus, increasing the survival of human dermal papilla cells [61]. It was noted that treatment with ginseng extract resulted in extended length of the anagen phase of hair growth, compared to controls [61]. Additionally, Park et al. also investigated the ability of red ginseng extract and associated ginsenosides to promote hair growth specifically in an in vitro human hair follicle cultures and in an in vivo C57BL/6 murine model [62]. In the in vitro model, they found that application of red ginseng resulted in increased proliferation of human dermal papilla cells, particularly keratinocytes, whereas improved hair growth was also observed in the in vivo murine model [62].

More recent studies have added substantial evidence to support the benefits that ginseng nutraceuticals can add to standard treatments of hair loss [63,64]. Keum et al. demonstrated the ability of Korean Red Ginseng (KRG) to inhibit alopecia in chemotherapy-related hair loss [63]. It was found that Korean Red Ginseng was able to block cyclophosphamide-induced hair loss in an ex vivo human hair organ culture by inhibiting cyclophosphamide-induced apoptosis of keratinocytes [63]. This inhibition was mediated by inhibition of cyclophosphamide-induced increases in expression of p53 and BAX and inhibition of cyclophosphamide-induced decreases in BCL2 expression [63]. Lee et al. further demonstrated the ability of Panax ginseng extract to 
increase cell growth and inhibit apoptosis of keratinocytes, by increasing gene expression of BCL2 and inhibiting gene expression of BAX [64]. They also found that the ginseng extract blocked DKK-1 induced hair growth inhibition in an ex vivo human hair culture [64].

The potent hair regenerative properties of ginseng have also been well-documented in murine models. Murata et al. investigated the hair regenerative properties of ginseng rhizome and Ginsenoside Ro in treating androgenetic alopecia [65]. Researchers found that ginseng rhizome was able to inhibit testosterone 5-alpha reductase in a dose-dependent manner [65]. They also demonstrated that ginseng rhizome and ginenosidero blocked testosterone-induced hair growth suppression in a C57BL/6 murine model [65]. They concluded that ginseng rhizomes containing oleanane- and dammarane-ginsenosides were capable of enhancing hair growth to treat androgenetic alopecia [65]. Li et al. investigated the mechanisms by which Ginsenosides, a main component of ginseng, are able to promote hair growth [66]. By comparing treatment of topical ginsenosides to a control treatment in a C57BL/6 murine model, researchers found that ginsenosides resulted in increased detection of p63, a modulator of keratinocyte stem cells, in the treatment group [66]. They concluded that activation of $\mathrm{p} 63$, is a potentially novel mechanism by which ginsenosides exert their effects within the dermis and epidermis [66].

To build on these, Truong et al. demonstrated the hair regenerative abilities of topical red ginseng oil in a C57BL/6 murine model pre-treated with testosterone to induce delayed hair growth [67]. They found that topical red ginseng oil displayed similar hair growth properties as linoleic acid (LA) and beta-sitosterol (SITOS), through upregulation of Wnt/Beta-catenin and Shh/Gli pathways [67]. Red ginseng oil was uniquely found to increase expression of BCL-2, an antiapoptotic modulator, which further enhances the survival of dermal follicular cells [67].

In addition to ginseng, a novel study by researchers from Chungnam National University in the Republic of Korea found that the natural herb Eclipta Alba could have even more potent hair regenerative properties compared to ginseng [68]. E. Alba is a traditional medicinal herb that has been used widely in Asian and Ayurvedic alternative medicines. They investigated the ability of panax ginseng to promote hair growth in nude mice, when either compared to or combined with other herbs with follicular therapeutic properties [68]. Interestingly, it was found that nude mice treated with panax ginseng extract did not differ significantly from controls in a number of measures, including hair density and staging of hair morphogenesis [68]. Instead, they found that the herbal compound known as E. alba was much more effective in promoting hair regeneration in nude mice, exhibiting higher hair length and hair density measurements [68]. Further research should be done to further characterize the beneficial effects of E. alba as another potent mediator

The potent hair growth promoting characteristics of ginseng in pre-clinical studies have prompted researchers to test the safety and efficacy of ginseng in treating hair loss in clinical models. Oh and Son investigated the ability of Korean Red Ginseng (KRG) to treat alopecia areata in conjunction with a standard corticosteroid treatment compared to treatment with a corticosteroid alone, in a trial of 50 patients [69]. It was found that patients treated with ginseng in conjunction with a standard corticosteroid exhibited higher levels of hair density, hair thickness, and hair growth by visual assessment, when compared to groups receiving only the corticosteroid treatment 
[69]. Importantly, these differences were not statistically significant, indicating a need for further studies done with potentially larger sample sizes [69]. A 2014 study by Ryu et al. further supports these findings by illustrating that minoxidil in conjunction with Korean red ginseng was much more effective than minoxidil alone in treating female pattern baldness [70]. In a trial of 41 female patients randomly assigned to either a standard minoxidil treatment or a combined minoxidil and Korean red ginseng treatment, those receiving the combination treatment exhibited greater hair density and hair thickness compared to the standard treatment, although it is important to note these differences were not statistically significant [70].

In addition to these studies illustrating the promotion of hair growth, key studies have been done elucidating potential mechanisms of action behind ginseng's effects on epidermal cell populations. Kim et al. produced evidence that suggests panax ginseng may exert its effects in a similar mechanism to minoxidil, a current FDA-approved hair loss therapeutic [71]. In an ex vivo model of human hair follicle organs, researchers found that panax ginseng resulted in an increase in cellular proliferation of human dermal papilla cells, increased expression of VEGF, and increased activation of potassium channels, in dose-dependent manners [71].

In order to further elucidate the mechanisms underlying the hair promoting abilities of ginseng and ginsenosides, Shin et al. demonstrated that Ginsenoside Rg3 led to an increase in expression of VEG-F in both human dermal papilla cells and murine hair follicles [72]. Thus, there is high probability that ginsenosides, particularly Ginsenoside $\mathrm{Rg} 3$, stimulates hair growth through interaction with epidermal stem cells [72]. In another study by Li et al., researchers found that panax ginseng, and its associated ginsenosides, promoted hair growth in both in vivo and ex vivo murine models [73]. They also found evidence to suggest that this hair growth was mediated through ginsenoside-induced inhibition of TGF-b pathways within the epidermis [73].

Researchers have also characterized novel bioactive compounds within panax ginseng as mediators of ginseng's potent effects on hair growth [74]. Whereas the hair regenerative properties of ginseng had been traditionally been attributed to saponins, Suzuki et al. found evidence suggesting that it was polyacetylene bioactive compounds contained within ginseng that play a large role in hair growth via inhibition of neurotrophin-receptor binding [74]. The evidence for ginseng in playing important roles in hair growth is extensive. In addition to the numerous other health benefits it provides, sufferers of hair loss might consider adding ginseng-based options, such as ginseng tea, into their normal dietary routines.

As evidenced in Table 4, numerous in vivo and in vitro studies have provided strong evidence supporting the causal association between ginseng and hair growth. Both C57BL/6 murine models and dermal papillae cell cultures were consistently used, however, these studies were limited by a lack of dosing consistency and consistency in type of ginseng, with some using panax ginseng, korean red ginseng, and ginsenosides. While two clinical experiments were conducted, detailed information regarding dosing was limited and results varied with regard to significance. Additionally, one study administered ginseng via tablet or capsule form, which would prevent it from being classified as a functional food [70]. Future research should be done to focus on clinicalbased testing with ginseng in non-tablet or capsule forms. 
Table 4. Summary of Research on Ginseng-based Hair Growth Studies

\begin{tabular}{|c|c|c|c|c|}
\hline Study & Type of Study & $\begin{array}{l}\text { Intervention and/or } \\
\text { Bioactive Ingredients }\end{array}$ & Dosage and Administration Time & Outcome \\
\hline \multirow[t]{2}{*}{$\begin{array}{l}\text { Park et } \\
\text { al., 2011 } \\
\quad[61]\end{array}$} & $\begin{array}{l}\text { In vitro cell line } \\
\text { (human dermal } \\
\text { papilla cells) }\end{array}$ & $\begin{array}{l}\text { Fructus panax ginseng } \\
\text { (FPG) extract }\end{array}$ & $\begin{array}{l}\text { In vitro: } 10 \mu \mathrm{l} \text { of FPG extract with } \\
\text { increasing doses }(0.8,4,20,100 \text {, } \\
500 \mu \mathrm{g} / \mathrm{ml}) \text { for } 24,48 \text {, and } 72 \text { hours }\end{array}$ & $\begin{array}{l}\text { In vitro: Increased proliferation, } \\
\text { upregulated Bal-2, and downregulated } \\
\text { Bax in human dermal papilla cells }\end{array}$ \\
\hline & $\begin{array}{l}\text { In vivo (C57BL/6) } \\
\text { mouse model }\end{array}$ & & $\begin{array}{c}\text { In vivo: } 100 \mu \mathrm{l} \\
1 \mathrm{mg} / \mathrm{ml} \text { FPG extract per day for } 21 \\
\text { days with data collected at } 1,4,7, \\
14, \text { and } 21 \text { days }\end{array}$ & $\begin{array}{l}\text { In vivo: Improved hair growth, including } \\
\text { lengthened anagen phase cycling }\end{array}$ \\
\hline $\begin{array}{l}\text { Murata et } \\
\text { al., 2012 } \\
{[65]}\end{array}$ & $\begin{array}{l}\text { In vivo }(\mathrm{C} 57 \mathrm{BL} / 6) \\
\text { mouse model }\end{array}$ & $\begin{array}{l}\text { Topical red ginseng } \\
\text { rhizomes } \\
\text { ( } 2 \mathrm{mg} / \mathrm{mouse}) \text { and } \\
\text { ginsenoside Ro } \\
(0.2 \mathrm{mg} / \mathrm{mouse})\end{array}$ & $\begin{array}{c}100 \mu \mathrm{L} 2 \%(\mathrm{w} / \mathrm{v}) \mathrm{RG} \text { rhizome extract } \\
\text { or } 0.2 \%(\mathrm{w} / \mathrm{v}) \text { ginsenoside Ro1/day } \\
30 \mathrm{~min} \text {. following } 100 \mu \mathrm{L} \\
\text { testosterone treatment for } 30 \text { days }\end{array}$ & $\begin{array}{l}\text { Ginenoside contents are highest in the } \\
\text { rhizome region of the ginseng plant; } \\
\text { rhizomes and ginenosides inhibit 5a- } \\
\text { reductase and promoted hair re- } \\
\text { growth. }\end{array}$ \\
\hline $\begin{array}{l}\text { Li et al., } \\
2013[66]\end{array}$ & $\begin{array}{l}\text { In vivo }(\mathrm{C} 57 \mathrm{BL} / 6) \\
\text { mouse model }\end{array}$ & $\begin{array}{l}\text { Protopanaxadiol-type } \\
\text { ginsenosides } \mathrm{Rb} 1 \text { and } \\
\mathrm{Rd}\end{array}$ & $\begin{array}{l}300 \mathrm{mg} \text { or } 1.5 \mathrm{ml} \text { per kg body weight } \\
\text { of } 5 \mathrm{mg} / \mathrm{ml} \text { protopanaxadiol-type } \\
\text { ginsenosides } \mathrm{Rb} 1 \text { and } \mathrm{Rd} 35 \text { in } 20 \% \\
9: 1 \text { ethanol:methanol for } 35 \text { days }\end{array}$ & $\begin{array}{l}\text { Increased hair growth, potentially } \\
\text { through upregulation of p63 signaling. }\end{array}$ \\
\hline $\begin{array}{l}\text { Begum et } \\
\text { al., } 2014 \\
{[68]}\end{array}$ & $\begin{array}{l}\text { Athymic Balb/c } \\
\text { male nude mice }\end{array}$ & $\begin{array}{l}\text { Eclipta alba, Asiasari } \\
\text { radix, and Panax } \\
\text { ginseng extracts }\end{array}$ & $\begin{array}{l}\text { 2.5\% daily application of } A \text {. radix, E. } \\
\text { alba, and P. ginseng extracts for } 2 \\
\text { hair growth cycles }\end{array}$ & $\begin{array}{l}\text { Highest effectiveness of the three } \\
\text { compounds tested for promoting hair } \\
\text { loss was E. Alba }\end{array}$ \\
\hline $\begin{array}{l}\text { Ryu et al., } \\
2014 \text { [70] }\end{array}$ & $\begin{array}{l}\text { Active control } \\
\text { trial with } 41 \\
\text { female pattern } \\
\text { hair loss patients }\end{array}$ & $\begin{array}{l}\text { Only topical 3\% } \\
\text { minoxidil or topical } 3 \% \\
\text { minoxidil and oral } \\
\text { Korean Red Ginseng } \\
\text { (KRG) }\end{array}$ & $\begin{array}{c}1 \text { oral capsule per day for } 24 \text { weeks } \\
\text { with data collected before } \\
\text { treatment, at } 12 \text { weeks, and at } 24 \\
\text { weeks }\end{array}$ & $\begin{array}{l}\text { Improved hair density by } 13 \% \text { and hair } \\
\text { thickness by } 21 \% \text { (note: not statistically } \\
\text { significant). }\end{array}$ \\
\hline $\begin{array}{l}\text { Shin et } \\
\text { al., } 2014 \\
{[72]}\end{array}$ & $\begin{array}{l}\text { In vivo }(\mathrm{C} 57 \mathrm{BL} / 6) \\
\text { mouse model }\end{array}$ & & $\begin{array}{l}\text { In vivo: } 100,500, \text { or } 1000 \mu \mathrm{MRg} 3 \\
\text { daily for } 1 \text { week }\end{array}$ & $\begin{array}{l}\text { In vivo: Increased stemness markers } \\
\qquad \mathrm{CD} 8, \mathrm{CD} 34 \text {, and } \mathrm{Ki}-67\end{array}$ \\
\hline $\begin{array}{l}\text { Kim et al., } \\
2015[71]\end{array}$ & $\begin{array}{l}\text { In vitro cell line } \\
\text { (human dermal } \\
\text { papilla cells and } \\
\text { anagen hair } \\
\text { follicles) }\end{array}$ & $\begin{array}{l}\text { Ginsenoside-enriched } \\
\text { Panax ginseng (PG) } \\
\text { extract }\end{array}$ & $\begin{array}{c}2,5 \text { and } 10 \mu \mathrm{g} / \mathrm{ml} \mathrm{PG} \text { extracts and } 1 \\
\mu \mathrm{M} \text { of the ginsenosides Rb1, Re and } \\
\text { Rg1 for } 5 \text { days }\end{array}$ & $\begin{array}{l}\text { Increased dermal cell proliferation, } \\
\text { increased BEGF expression, and hair } \\
\text { growth promotion }\end{array}$ \\
\hline \multirow[t]{2}{*}{$\begin{array}{l}\text { Park et } \\
\text { al., 2015 } \\
\text { [62] }\end{array}$} & $\begin{array}{l}\text { In vitro cell line } \\
\text { (human dermal } \\
\text { papilla cells and } \\
\text { keratinocytes) }\end{array}$ & $\begin{array}{l}\text { Korean red ginseng } \\
\text { extract (RGE) }\end{array}$ & $\begin{array}{l}\text { In vitro: } \\
\text { - Papilla cells }-15 \text { mins } 0-300 \\
\mathrm{lg} / \mathrm{mL} \text { RGE or } 0-15 \mathrm{lg} / \mathrm{mL} \\
\text { ginsenoside-Rb1 } \\
\text { - Keratinocytes }-100 \mathrm{lg} / \mathrm{mL} \text { RGE } \\
\text { or } 10 \mathrm{lg} / \mathrm{mL} \text { ginsenoside-Rb1 for } \\
2 \text { days }\end{array}$ & $\begin{array}{c}\text { In vitro: Increased dermal cell and } \\
\text { keratinocyte proliferation, upregulation } \\
\text { of ERK and AKT pathways }\end{array}$ \\
\hline & $\begin{array}{l}\text { In vivo }(\mathrm{C} 57 \mathrm{BL} / 6) \\
\text { mouse model }\end{array}$ & & $\begin{array}{l}\text { In vivo: } 100 \mu \mathrm{l} \text { subcutaneous } \\
\text { injection of } 3 \% 100 \mathrm{mg} / \mathrm{mL} \text { RGE } \\
\text { every other day for } 7 \text { weeks }\end{array}$ & In vivo: Increases hair growth \\
\hline
\end{tabular}




\begin{tabular}{|c|c|c|c|c|}
\hline Study & Type of Study & $\begin{array}{l}\text { Intervention and/or } \\
\text { Bioactive Ingredients }\end{array}$ & Dosage and Administration Time & Outcome \\
\hline $\begin{array}{l}\text { Keum et } \\
\text { al., } 2016 \\
\text { [63] }\end{array}$ & $\begin{array}{l}\text { Human } \\
\text { hair follicle organ } \\
\text { culture model }\end{array}$ & $\begin{array}{l}\text { Korean red ginseng } \\
\text { (KRG) }\end{array}$ & $\begin{array}{l}\text { Pre-treatment with } 100 \mathrm{mg} / \mathrm{mL} \text { or } \\
500 \mathrm{mg} / \mathrm{mL} \text { KRG for } 1 \text { day prior to } \\
\text { cyclophosphamide } 1 \text { day incubation }\end{array}$ & $\begin{array}{l}\text { Protects against cyclophosphamide- } \\
\text { induced hair loss, premature catagen, } \\
\text { keratinocyte downregulation and } \\
\text { apoptosis, and p53 and } \mathrm{Bax} / \mathrm{Bcl} 2 \\
\text { downregulation. }\end{array}$ \\
\hline \multirow[t]{2}{*}{$\begin{array}{l}\text { Li et al., } \\
2016[73]\end{array}$} & $\begin{array}{l}\text { In vitro cell line } \\
\text { (vibrissa hair } \\
\text { follicles and HeLA } \\
\text { cells) }\end{array}$ & Ginsenoside $\operatorname{Re}(\mathrm{GRe})$ & $\begin{array}{l}\text { In vitro: } \\
\text { - Vibrissa follicles - 10, } 50 \mathrm{mg} / \mathrm{L} \\
\text { ginsenoside Re } \\
\text { - HeLA cells }-10 \mathrm{mg} / \mathrm{L} \\
\text { ginsenoside Re }\end{array}$ & $\begin{array}{l}\text { In vitro: Hair shaft growth in cultured } \\
\text { vibrissa hair follicles and upregulation } \\
\text { of ERK signaling in HeLa cells }\end{array}$ \\
\hline & $\begin{array}{l}\text { In vivo (C57BL/6) } \\
\text { mouse model }\end{array}$ & & $\begin{array}{c}\text { In vivo: } 1 \mathrm{mg} / \mathrm{d} \text { and } 5 \mathrm{mg} / \mathrm{d} \\
\text { ginsenoside } \mathrm{Re} \text { daily for } 45 \text { days }\end{array}$ & $\begin{array}{c}\text { In vivo: Early onset and elongated } \\
\text { anagen phase, downregulation of TGF-b } \\
\text { signaling }\end{array}$ \\
\hline $\begin{array}{l}\text { Lee et al., } \\
2017[64]\end{array}$ & $\begin{array}{l}\text { In vitro cell line } \\
\text { (human } \\
\text { keratinocyte) and } \\
\text { human hair } \\
\text { follicle organ } \\
\text { culture }\end{array}$ & $\begin{array}{c}\text { Panax ginseng (PG) } \\
\text { extract }\end{array}$ & $\begin{array}{c}\text { In vitro: } 20 \text { ppm PG extract or } 1 \mu \mathrm{M} \\
\text { ginsenosides with or without DKK-1 } \\
\text { for } 1 \text { day incubation } \\
\text { Organ culture: } 20 \text { ppm or } 50 \mu \mathrm{M} \mathrm{PG} \\
\text { extract renewed every } 2 \text { days for } 7 \\
\text { days }\end{array}$ & $\begin{array}{c}\text { Increased proliferation and decreased } \\
\text { apoptosis in keratinocytes, inhibited } \\
\text { DKK-1 and Bax expression, increased } \\
\text { BCl-2 expression. }\end{array}$ \\
\hline $\begin{array}{l}\text { Truong et } \\
\text { al., } 2017 \\
\text { [67] }\end{array}$ & $\begin{array}{l}\text { In vivo (C57BL/6) } \\
\text { mouse model }\end{array}$ & Red Ginseng Oil (RGO) & $10 \%$ RGO daily for 28 days & $\begin{array}{l}\text { Restoration of hair growth in mice pre- } \\
\text { treated with testosterone-induced } \\
\text { anagen delay, upregulation of Wnt/b- } \\
\text { catenin and Shh/Gli signaling, and } \\
\text { increased Bcl- } 2 \text { but decreased TGF-b } \\
\text { expression. }\end{array}$ \\
\hline $\begin{array}{l}\text { Suzuki et } \\
\text { al., } 2017 \\
\text { [74] }\end{array}$ & $\begin{array}{l}\text { Neurotrophin } \\
\text { Receptor Binding } \\
\text { Inhibition Assay }\end{array}$ & $\begin{array}{c}\text { Various polyacetylenes } \\
\text { isolated from Panax } \\
\text { Ginseng }\end{array}$ & $\begin{array}{c}\text { 10, 30, and } 100 \mu \mathrm{M} \text { sample solution } \\
\text { of each polyacetylene isolated from } \\
\text { Panax Ginseng }\end{array}$ & $\begin{array}{l}\text { Inhibition of brain-derived neurotrophic } \\
\text { factor (BDNF)-TrkB and } \beta \text {-nerve growth } \\
\text { factor ( } \beta \text {-NGF)-p75 neurotrophin } \\
\text { receptor ( } p 75 N T R \text { ) binding, highly due } \\
\text { to hydroxyl moiety. }\end{array}$ \\
\hline
\end{tabular}

\section{ANNURCA APPLE POLYPHENOLS}

\section{Annurca Apple as a Candidate Functional Food}

The Annurca Apple is type of apple commonly cultivated in Southern Italy. Highly abundant within these apples are polyphenols, specifically flavonoids, exhibiting high antioxidant, anticancer, antiproliferative, and antiatheroslcerotic activities. Clinical research has shown that Annurca apple consumption is capable of reducing hypercholesterolemia and creating healthy plasma cholesterol balances [75]. While polyphenols of Annurca apple are known to serve as antioxidants, Annurca apple nutraceuticals have also been shown in vitro to have pro-oxidant and pro-apoptotic effects when directed towards tumorigenic cell types, including breast cancer cell lines, in addition to protective effects against cell stress and cell aging in normal cells [76, 77]. Evidence also suggests that Annurca apple polyphenols have dose-dependent manner free-radical scavenging abilities. [77]. Polyphenols from the Annurca Apple have also been shown to have promising positive, therapeutic effects on skin diseases, including psoriasis and dermatitis [76].

\section{Annurca Apple for Treating Hair Loss}

Two key studies have been conducted investigating the potential relationship between Annurca apple and hair growth (Table 5) [78, 79]. Ricco et al. demonstrated that an Annurca Apple Polyphenolic Extract (AAE) possesses hair growth promoting abilities, in specific regard to 
treating chemotherapy-induced alopecia (CIA), although it is likely Annurca Apple can also be applied to other hair loss disorders [78]. Researchers found that Annurca Apple was able to protect follicular cells from taxane-induced dystrophy in a mouse model, through shunting of ATP production to mitochondrial beta-oxidation, and downregulation of the pentose phosphate pathway (PPP) and subsequent reduction of nucleotide production and DNA replication [78]. Simultaneously, they found that Annurca Apple also promoted hair growth via upregulation of prostaglandins [78].

Researchers have also isolated polyphenols from the Annurca Apple and created a nutraceutical formulation called Apple Mets, that was topically applied in both in vitro cell lines and a clinical trial model [79]. The Annurca Apple nutraceutical formulation improved cell viability and keratin production in vitro and improved hair growth, density, and keratin content in human subjects [79]. While Annurca apples may be difficult to acquire given their nativity to Italy, Annurca apple-based nutraceutical formulations are potent options that, once approved and marketed, can contribute to natural-based remedies for preventing or treating hair loss.

Table 5. Summary of Research on Annurca Apple-based Hair Growth Studies

\begin{tabular}{|c|c|c|c|c|}
\hline Study & Type of Study & $\begin{array}{l}\text { Intervention and/or Bioactive } \\
\text { Ingredients }\end{array}$ & $\begin{array}{c}\text { Dosage and } \\
\text { Administration Time }\end{array}$ & Outcome \\
\hline \multirow[t]{2}{*}{$\begin{array}{l}\text { Ricco et } \\
\text { al., } 2018 \\
\quad[78]\end{array}$} & $\begin{array}{l}\text { Ex vivo }(\mathrm{C} 57 \mathrm{BL} / 6) \\
\text { mouse model }\end{array}$ & $\begin{array}{l}\text { Annurca Apple Extract (AAE) } \\
\text { AnnurtriComplex formulation } \\
\text { (MB-Med: Turin, Italy) }\end{array}$ & $\begin{array}{l}\text { Ex vivo: } 400 \mathrm{mg} / \mathrm{L} \text { AAE } \\
\text { renewed every } 3 \text { days } \\
\text { incubated for } 8 \text { days }\end{array}$ & $\begin{array}{l}\text { Increased PUFA content } \\
\text { and PUFA b-oxidation; } \\
\text { follicular protection and } \\
\text { keratin preservation } \\
\text { against taxane-induced } \\
\text { dystrophy }\end{array}$ \\
\hline & $\begin{array}{l}\text { In vivo (C57BL/6) } \\
\text { mouse model }\end{array}$ & & $\begin{array}{l}\text { In vivo: } 2 \mathrm{~cm}^{3} \mathrm{AAE} \\
\text { foam (containing } \\
\text { AnnurtriComplex } 6 \% \\
(\mathrm{w} / \mathrm{v}) \text { ) for } 4 \text { weeks }\end{array}$ & \\
\hline \multirow[t]{2}{*}{$\begin{array}{l}\text { Tenore et } \\
\text { al., } 2018 \\
\text { [79] }\end{array}$} & $\begin{array}{l}\text { In vitro cell line } \\
\quad \text { (human } \\
\text { keratinocytes) }\end{array}$ & $\begin{array}{l}\text { In vitro: Annurca apple-based } \\
\text { formulation, AppleMetS }\end{array}$ & $\begin{array}{l}\text { In vitro: } 0.23 \text { and } 0.46 \\
\mathrm{mg} / \mathrm{mL} \text { AppleMetS } \\
\text { over } 48 \text {-hour range }\end{array}$ & $\begin{array}{l}\text { In vitro: Enhanced keratin } \\
\text { production }\end{array}$ \\
\hline & $\begin{array}{l}\text { 16-week, } \\
\text { randomized, } \\
\text { double-blind, } \\
\text { placebo-controlled } \\
250 \text { patient trial }\end{array}$ & $\begin{array}{l}\text { Clinical trial: Annurca apple } \\
\text { formulation* or placebo } \\
\text { *(1) AMS: AFA polyphenol } \\
\text { extract + maltodextrins } \\
\text { (2) AMSbz: AFA polyphenol + } \\
\text { maltodextrins, biotin, } \\
\text { selenomethionine, zinc acetate }\end{array}$ & $\begin{array}{l}\text { Clinical trial: } 2 \text { gastric- } \\
\text { resistant } \\
\text { capsules/day of AMS } \\
\text { or AMSbzs orally ( } 1 \\
\text { evening and } 1 \\
\text { morning) for } 16 \\
\text { weeks }\end{array}$ & $\begin{array}{c}\text { Clinical trial: Increased hair } \\
\text { number by } 125 \% \text {, hair } \\
\text { weight by } 42 \% \text {, and keratin } \\
\text { content by } 40 \%\end{array}$ \\
\hline
\end{tabular}

In summary, the potential connection between Annurca apple and hair growth is promising but is limited to a few research studies. The in vivo and in vitro study provide a mechanistic basis for Annurca apple's effect on hair growth, but are lacking in dosing consistency and duration of administration. While the clinical trial possessed a large sample size, it did not address potential weaknesses in adherence to treatment or compare pre-protocol versus intent-to-treat analysis. Furthermore, the use of capsule-based administration of Annurca apple prevents its consideration as a functional food product [79]. Thus, further research should be done focused on direct oral consumption of Annurca apple with large sample sizes in a clinical setting.

\section{THUJA ORIENTALIS}


Thuja orientalis is an evergreen coniferous tree found mainly in East Asia, where it has been traditionally used in herbal medicine. Essential oils extracted from this tree have been shown to contain high levels of bioactive sesquiterpenes, which have been shown to have anti-proliferative characteristics [80]. Thus, it is not surprising that Thuja orientalis possesses strong anti-cancer properties, including protective capabilities against breast cancer as demonstrated in murine models [81], brain cancer, through antiproliferative and proapoptotic effects on cancer cells [82] and lung cancer, in a zebrafish-based teratogenic assay [83]. Research has shown that these antineoplastic properties may also be due to immunomodulation of key immune cell populations, particularly proliferation of B and T immune cells [84]. Having commonly been used in treating amenorrhea, cystitis, and uterine cancer, Thuja orientalis has also been shown to be a potent natural therapeutic in the treatment of polycystic ovary syndrome [85].

Thuja orientalis extracts were also shown to have antiviral efficacy, specifically anti-influenza activity, inducing improved cell viability following influenza infection in an in vitro model [86]. Thuja orientalis displays antioxidant properties [87] in addition to protective capabilities against dermatologic conditions, including atopic dermatitis, through anti-inflammatory activity [106]. These anti-inflammatory properties have also been shown to be beneficial in reducing inflammation of the airway in an asthmatic murine model [88]. Research has shown a portion of the anti-inflammatory properties of Thuja orientalis may be due to a labdane diterpene that induces suppression of NF-kB signal transduction and phosphorylation of the ERK protein [89]. Further research has also shown the anti-inflammatory potential of Thuja orientalis may be due to downregulation of neutrophils, cyclooxygenase and prostaglandin activity, ad TNF-a signal transduction [90].

\section{Thuja Orientalis for Treating Hair Loss}

Detailed in Table 6, preliminary research has shown that Thuja orientalis may also serve as a potent natural therapeutic for treating various forms of hair loss [91]. Zhang et al. demonstrated that topical application of Thuja orientalis extract to shaved C57BL/6 mice arrested in the telogen phase resulted in progression into the anagen phase of follicular development [91]. In addition to an earlier progression into the anagen phase, compared to the control or minoxidil drug, Thuja orientalis treated mice also exhibited a lengthened anagen phase, mediated by upregulation of Bcatenin and Shh pathways [91]. Although research regarding Thuja orientalis as a natural formulation for treating hair loss is still in its early stages, it provides promising results for a natural topical-based nutraceutical formulation to support hair growth. Future research should investigate the effects of Thuja orientalis in a clinical model.

Table 6. Summary of Research on Thuja orientalis-based Hair Growth Studies

\begin{tabular}{|c|c|c|c|c|}
\hline Study & Type of Study & $\begin{array}{l}\text { Intervention and/or } \\
\text { Bioactive Ingredients }\end{array}$ & $\begin{array}{c}\text { Dosage and Administration } \\
\text { Time }\end{array}$ & Outcome \\
\hline $\begin{array}{l}\text { Zhang et } \\
\text { al., } 2013 \\
\text { [91] }\end{array}$ & $\begin{array}{c}\text { In vivo } \\
(\mathrm{C} 57 \mathrm{BL} / 6) \\
\text { mouse model }\end{array}$ & $\begin{array}{c}\text { Thuja orientalis } \\
\text { extract }\end{array}$ & $\begin{array}{c}5.05 \mathrm{mg} / \mathrm{cm} 2 \text { or } 200 \mu \mathrm{l} \text { per day } \\
\text { of Thuja orientalis extract for } \\
21 \text { days with data recorded at } \\
0,7,14 \text {, and } 21 \text { days }\end{array}$ & $\begin{array}{l}\text { Induction of earlier and prolonged } \\
\text { anagen phase, increased hair } \\
\text { follicle size and count, and } \\
\text { expression of B-catenin and Shh } \\
\text { proteins. }\end{array}$ \\
\hline
\end{tabular}

\section{SUPPLEMENT NUTRACEUTICAL}


Marine ecosystems are an abundant resource for human health and nutrition. There are numerous marine organisms that have been looked to for biomedical and biofunctional uses, including fish, mollusks, bacteria, algae, cyanobacteria, sponges, and more. Marine fish, for instance, are abundant with protein, essential fatty acid, and vitamins and minerals, have been used in the treatment and management of many health conditions, including cancer, Alzheimer's, and hypertension [92]. Marine-derived peptides have been shown to have bioactive properties including antimicrobial, immunomodulatory, and antihypertensive characteristics through the function of ACE inhibition [92]. One major subset of marine supplements are algaebased foods, which are rich in amino acids, essential lipids such as long chain-polyunsaturated fatty acids and sterols, key polysaccharides including alginate, ulvans and laminarans, $\mathrm{B}$ and $\mathrm{C}$ vitamins, and inorganic iron and iodine [93]. These are thought to contribute to protective cardiovascular health benefits, improved cognitive functioning, and anticancer properties [93]. Algae is also rich is bioactive compounds, notably antioxidants and phytochemicals, carotenoids, anthocyanins, and phenols [93]. In regards to dermatological health algae is known for antiinfective, anti-aging, whitening, and skin cancer therapeutic uses [94].

\section{Marine Supplements for Treating Hair Loss}

The action of various marine nutraceuticals has been shown to display potent protective effects against hair loss (Table 7). Researchers at Jeju National University in Korea found that, Undariopsis peterseniana, an edible brown alga, increased hair length and progression into anagen phase in an in vivo murine model [95]. Furthermore, it was found that the mechanism behind this promotion of hair growth was potentially due to activation of potassium-ATP channels, reduction of 5-alpha-reductase activity, and upregulation of Wnt/ $\beta$-catenin and ERK pathways [95]. The Wnt/ $\beta$-catenin pathway has been extensively implicated in follicular development and subsequent hair growth while the ERK pathway has been associated with cellular proliferation. These are also the main pathways targeted by the drug, minoxidil, used to treat hair loss.

In addition to cell culture and murine models, clinical studies have also been conducted testing the efficacy of marine nutraceuticals in treating various forms of hair loss [96, 97, 98]. Ablon et al. utilized a randomized, double-blind, placebo-controlled trial to investigate the ability of a marine supplement to treat thinning hair in men [96]. They found the treatment group exhibited increases in total hair count, total hair density, and terminal hair density, in addition to improved visual assessment of hair growth by study investigators [96]. Additionally, key reviews by Hornfeldt et al. in 2015 and Hornfeldt in 2018 further details an open-label pilot study by Stephens et al. and numerous subsequent randomized, double-blind, control trials, investigating the ability of an oral marine formulation, particularly Viviscal $®$ (Lifes2good, Inc., Chicago, IL), to treat hair thinning in both males and females [97, 98]. These studies utilized oral marine supplement containing shark and mollusk powder, silica, and acerola cherry-based Vitamin C, biotin, and zinc $[97,98]$. Collectively in these studies, subjects receiving the marine treatment displayed overall greater increases in amount of hair and hair diameter, with additional improvement in self-reported hair volume, scalp coverage, hair shine, and other Quality of Life and Self-Assessment measurements [97, 98]. These findings demonstrate the potent benefits of adding marine supplements into new or current supplement regimens for individuals seeking to prolong initiation of hair loss or manage current hair loss.

Table 7. Summary of Research on Marine-based Hair Growth Studies 


\begin{tabular}{|c|c|c|c|c|}
\hline Study & Type of Study & $\begin{array}{l}\text { Intervention and/or } \\
\text { Bioactive Ingredients }\end{array}$ & $\begin{array}{c}\text { Dosage and } \\
\text { Administration Time }\end{array}$ & Outcome \\
\hline $\begin{array}{l}\text { Ablon, } \\
2016 \\
{[96]}\end{array}$ & $\begin{array}{l}\text { 6-month, } \\
\text { randomized, } \\
\text { double-blind, } \\
\text { placebo-controlled } \\
\text { trial of } 60 \text { subjects }\end{array}$ & $\begin{array}{c}\text { Marine complex } \\
\text { supplement (Viviscal }{ }^{\circledR} \\
\text { Man; Lifes2good, Inc., } \\
\text { Chicago, IL, USA) }\end{array}$ & $\begin{array}{c}2 \text { tablets/day ( } 1 \text { morning } \\
\text { and } 1 \text { evening) for } 6 \\
\text { months }\end{array}$ & $\begin{array}{c}\text { Increased hair count by } 8 \% \text {, hair } \\
\text { density by } 8 \% \text {, terminal hair density } \\
\text { by } 7 \% \text {, less hair removed in hair pull } \\
\text { tests, and improved quality of life } \\
\text { measures. }\end{array}$ \\
\hline \multirow[t]{2}{*}{$\begin{array}{l}\text { Kang et } \\
\text { al., } 2017 \\
\text { [95] }\end{array}$} & $\begin{array}{l}\text { Ex vivo model of Rat } \\
\text { Vibrissa Follicles; In } \\
\text { vivo (C57BL/6) } \\
\text { mouse model }\end{array}$ & $\begin{array}{c}\text { Undariopsis } \\
\text { peterseniana, an } \\
\text { edible brown alga, } \\
\text { extract }\end{array}$ & $\begin{array}{l}\text { Ex vivo: }(1,10 \text {, and } 100 \\
\mu \mathrm{g} / \mathrm{mL} \text { per day for } 21 \\
\text { days with data recorded } \\
\text { at } 0,7,14 \text {, and } 21 \text { days }\end{array}$ & $\begin{array}{c}\text { Ex vivo: Increased rat vibrissa } \\
\text { follicle length by } 206.5 \% \text { and } \\
165.6 \% \text {, via } 1 \mu \mathrm{g} / \mathrm{mL} \text { and } 10 \mu \mathrm{g} / \mathrm{mL} \\
\text { respectively }\end{array}$ \\
\hline & In vivo & & $\begin{array}{c}\text { In vivo: } 0.1,1, \text { and } 10 \\
\mu \mathrm{g} / \mathrm{mL} \text { per day for } 34 \\
\text { days }\end{array}$ & $\begin{array}{l}\text { In vivo: Increased induction into } \\
\text { anagen phase, inhibition of } 5 \alpha- \\
\text { reductase by up to } 42 \% \text {, increased } \\
\text { proliferation of dermal papilla cells } \\
\text { up to } 150 \% \text {, increased Wnt/b- } \\
\text { catenin and ERK signaling }\end{array}$ \\
\hline
\end{tabular}

While the aforementioned murine model and clinical trial display encouraging results for using murine-based supplements to improve hair growth, further research, particularly clinical studies, should be done to evaluate both the safety and efficacy of murine supplements on promotion of hair growth. The dosing and duration of administration between the mouse model and clinical trial vary widely; an additional limitation is the small sample of the clinical experiment. The use of tablet-based routes of administration limit the validity of marine supplements as potential functional foods [96]. Further studies should focus on direct, oral consumption of marine-based foods with large sample sizes in clinical settings.

\section{WATER-SOLUBLE EGG YOLK}

\section{Egg Yolks as a Candidate Functional Food}

In addition to being a rich source of dietary nutrients, egg yolks have been increasingly shown to serve as a potent healthy food in the management of a number of health conditions. Roughly $65 \%$ of the egg yolk is made up of lipids, including triacylglycerides, phospholipids, cholesterol, and free fatty acids, with roughly two-thirds consisting of monounsaturated and polyunsaturated fats [99]. These unsaturated fatty acids, particularly omega-3-fatty acids, have been shown to have protective benefits on cognitive and visual functioning [99]. In addition to lipids, egg yolks also contain high levels of both water-soluble and fat-soluble vitamins, including B vitamins and A, D, E, and $\mathrm{K}$ vitamins, respectively [99].

Egg yolk contains the enzyme lysozyme, which has been shown to have potent antimicrobial and antiviral activities. In particular, yolk immunoglobulins provide antigenic properties, ovalbumin-derived peptides display antihypertensive activity, yolk-derived phosphotin exhibits antioxidant properties, and egg albumen components display anti-cancer activities [99, 100]. Importantly, the high cholesterol content of egg yolks has prompted dietary suggestions to reduce consumption of egg yolks. Some studies have shown that dietary cholesterol has limited impacts on blood cholesterol concentrations, in comparison to endogenously produced cholesterol [101]. Nonetheless, these are important considerations and care should be taken when integrating eggbased functional food suggestions into hair loss treatment strategies for individuals concurrently diagnosed with hypercholesterolemia. 


\section{Egg Yolks for Treating Hair Loss}

While studies regarding the use of egg yolks in treating hair loss remains limited, one study has suggested that key peptides within egg yolks contain growth factor-stimulating properties that contribute to induction of hair growth (Table 8) [102]. Nakamura et al. found that water-soluble hair growth peptides (HGP) contained within egg yolks were capable of stimulating vascular endothelial growth factor (VEGF) and subsequent proliferation of human dermal papilla cells [102]. Hair growth was also observed in a murine model and in a female pattern hair loss model [102]. Additionally, they found that HGP likely promotes VEGF expression via activation of an insulin-like growth factor-1 receptor and subsequent induction of a hypoxia-inducible factor-1 $\alpha$ transcription pathway [102].

Table 8. Summary of Research on Egg-based Hair Growth Studies

\begin{tabular}{|c|c|c|c|c|}
\hline Study & Type of Study & $\begin{array}{l}\text { Intervention and/or } \\
\text { Bioactive Ingredients }\end{array}$ & $\begin{array}{c}\text { Dosage and } \\
\text { Administration Time }\end{array}$ & Outcome \\
\hline \multirow[t]{2}{*}{$\begin{array}{c}\text { Nakamura et } \\
\text { al., 2018 } \\
\text { [102] }\end{array}$} & $\begin{array}{l}\text { In vivo }(\mathrm{C} 3 \mathrm{H}) \\
\text { mouse model }\end{array}$ & $\begin{array}{l}\text { Water-soluble egg yolk } \\
\text { peptide (hair growth } \\
\text { peptide (HGP)) or } \\
\text { placebo }\end{array}$ & $\begin{array}{c}\text { In vivo: } 0.1 \%(w / w) \text { HGP } \\
\text { diet for } 17 \text { days }\end{array}$ & $\begin{array}{l}\text { In vivo: Increased VEGF } \\
\text { expression, dermal papilla } \\
\text { cell proliferation, and overall } \\
\text { murine hair growth. }\end{array}$ \\
\hline & $\begin{array}{l}\text { Randomized } \\
\text { placebo-controlled } \\
\text { trial of } 76 \text { subjects }\end{array}$ & & $\begin{array}{l}\text { Clinical trial: HGP tablet } \\
(250 \mathrm{mg}) \text { per day by oral } \\
\text { administration for } 24 \\
\text { weeks }\end{array}$ & $\begin{array}{l}\text { Clinical Trial: Increased hair } \\
\text { density and growth, via IGF-1 } \\
\text { receptor activation and VEGF } \\
\text { expression }\end{array}$ \\
\hline
\end{tabular}

Limitations of this study included a small sample size and lack of specific quantification of increased hair growth, which was instead qualitatively assessed via visual assessment. The therapeutic effects of egg yolk in treating hair loss appears quite promising, however, further investigations to determine its benefits on hair loss is necessary and until such time, substantial recommendations cannot be warranted. Future research should focus on clinical testing to evaluate the safety and efficacy of egg-yolk based treatments to increase hair growth

\section{HONEY}

Honey has been known for its natural therapeutic properties for thousands of years in cultures across the globe. While the major component of natural honey by weight consists of carbohydrate sugars, its therapeutic value is primarily attributed to the presence of over 300 bioactive compounds, including phenolic antioxidants, inhibine's rich in antibiotics, amino acids, vitamins, and minerals [103]. The uses of honey in treating ailments is widespread, ranging from chronic conditions such as diabetes and cancer to acute conditions such as gastrointestinal upset, menstrual pain, viral infection, fever, respiratory distress, and so on [103]. The antioxidative properties of honey are heavily attributed to its high concentrations of phenolic compounds, including flavonoids, as well as reducing sugars and amino acids, translating into protective effects against cardiovascular disease, metabolic syndrome, diabetes, and cognitive neurodegeneration [104]. It has also been shown that honey serves as a potent source of probiotics additionally serving as a prebiotic agent stimulating growth of intestinal flora by providing oligosaccharide-based energy 
sources for gut microbes [104]. Studies have also attempted to utilize propolis additives to honey in order to enhance the natural therapeutic properties of honey. It has been shown that the honey formulations with added propolis exhibited a boost in antimicrobial, antioxidant, and antiinflammatory properties [105].

Specifically pertaining to its effects within the integumentary system, the beneficial dermatological properties of honey are multifold. Firstly, honey has been growing in popularity as an effective wound healing agent [103]. In addition to moisturizing and hydration of healing wounds, honey also carries anti-inflammatory, antimicrobial, and antiseptic effects, all critical to wound healing processes [106]. In addition, honey has been shown to have involvement in cellular pathways that increase expression of tissue repair mediators and keratinocyte proliferation [106]. Honey has also been shown to have protective benefits in the treatment of acne, by reducing aqueous availability of water in the skin and thus preventing microbial growth [107]. While common commercial recommendations for hair loss prevention have revolved around the use of honey, research surrounding the ability of honey to promote hair growth remains relatively limited.

\section{EVALUATING SCIENTIFIC EVIDENCE: FFC's Standards for Functional Food Products}

Prior to creating functional food products, it is critical to first understand the definition of functional foods. Strictly speaking, functional foods have been not provided a standardized definition by any regulatory body in the United States, and a standardized definition across countries has not been established by global regulatory authority [108]. Examples of independent definitions developed by national and international agencies include: modified foods that provide health benefits beyond traditional nutrients, fortified and enriched foods to be consumed at intervals and amounts needed to derive health benefits, and substances that provide nutrients beyond those necessary for normal functioning [108]. However, as a front runner in advancing the field of functional foods, the latest definition by the Functional Food Center (FFC) for functional foods provides a unified, proper definition that aims to enable exchange of functional food knowledge and products across domestic and international borders. The latest definition is as follows, "Natural or processed foods that contain biologically-active compounds; which, in defined, effective non-toxic amounts, provide a clinically proven and documented health benefit utilizing specific biomarkers, for the prevention, management, or treatment of chronic disease or its symptoms." [7]. This definition highlights the importance of dosage consideration, natural or processed production, inclusion of bioactive compounds, and evidence of clinically proven and documented health benefits in the creation of functional food products. This definition will guide our evaluation of the foods that have been discussed in this paper, in determining if they can be recommended as a functional food product. In order to determine if the aforementioned foods can be established as functional food products for the prevention, treatment, and management of hair loss, a standardized review system linking scientific evidence to health claims is needed. While the US Food and Drug Administration (FDA) does not provide a strict definition for functional foods, it does provide an evidence-based review system for evaluating scientific evidence of health claims. A health claim establishes the relationship between a food product and a health-related condition. In order to establish authorized health claims, the FDA evaluates the extent of evidence supporting the claim and overall agreement among experts in the field, while those claims with extensive evidence but lacking overall agreement are deemed qualified health claims [109]. Additionally, the FFC has also developed a review system for the evaluation of functional food product scientific evidence, which integrate the FDA health claims 
described above. The system requires the following steps in order: researching a relationship between the food and health-related impacts, conducting in vitro and in vivo studies, identifying target bioactive compounds, and determining appropriate dosages and mechanisms of action [109]. Next, human studies with evaluation of safety and efficacy, development of appropriate food vehicles, labelling, establishing health claims, marketing and education, and post-marketing effectiveness and safety monitoring studies are required [109]. The FFC definition of functional foods, FDA evaluation of health claims, and FFC standards for functional food products will be used to determine the recommendation of aforementioned food items as functional food products for addressing hair loss.

\section{EVALUATING SCIENTIFIC EVIDENCE: Applying FDA and FFC Standards to Hair Growth-Promoting Functional Foods}

The FDA-proposed method of evaluation of health claims will first be applied to analyze the relationships between the aforementioned functional foods and treatment of hair loss. While both observational and interventional studies are valuable sources of information for analysis of health claims, observational studies do not provide causal conclusions and thus provide weaker evidence for causal relationships between food or food ingredients and hair loss conditions. Therefore, functional food items with intervention studies, both pre-clinical and clinical, will be focused on evaluating the validity of health claims. Six of the nine food ingredients: berries, rice bran, ginseng, Annurca apple, marine supplementation, and egg yolk, which were reviewed provided evidence for both pre-clinical and clinical testing of health claims. For each of these food items, the conclusion of each study was in general agreement regarding the beneficial effects on hair growth. Out of six potential functional food ingredients, ginseng provided the most extensive totality of evidence supporting its hair growth-promoting properties health claims. This totality of evidence and agreement among the conclusions of this scientific evidence provides support for the food product, ginseng, to promote hair growth and serves as a strong basis to continue research with the end goal of validating if ginseng can be confirmed as a functional food for the treatment of hair loss. Unfortunately, until further evidence is obtained, health claims regarding ginseng's impact on hair growth cannot be validated. Additionally, the remaining five food items also have potential to have authorized health claims on promotion of hair growth, but even more extensive evidence is needed prior to approving these health claims.

The FFC standards for establishing a functional food product will then be applied to determine if the food ingredients or products can be recommended as functional food products for the treatment of hair loss. Studies on all nine food ingredients were examined for their link to hair promotional capacities. Both in vitro and in vivo studies conducted in five of these nine food products namely, berries, Mediterranean diets, rice bran, ginseng, and Annurca apple found a target bioactive compound. In addition, all five of these also provided dosing regimens and potential mechanisms of action of the target bioactive compound. Moving stepwise down the FFC system for creation of functional food products, four of the five food items including berries, rice bran, ginseng, and Annurca apple were applied in human studies and vehicles of application were developed for each. In general, these were either oral or topical formulations. However, some of these ingredients were often administered in capsule or tablet form. Because the FFC's definition of functional foods delineates natural or processed food, but not capsules or tablets, further research aimed towards establishing these ingredients as functional foods must shift away from capsule or tablet administration. Health claims, all focused on promotion of hair growth, were 
made for each of these food items. These health claims were analyzed in the previous section with evidence for ginseng providing the greatest support for an approved health claim. Thus, out of the nine food items analyzed, ginseng is the strongest candidate to be considered a functional food product for the management of hair loss. Notably, in many cases, ginseng was not used as a food but rather as a tablet, and it was unclear if benefits of ginseng on hair growth were clinically associated with biomarkers. An additional limitation was that exact quantities of hair growth improvement were often not provided but were determined through visual ascertainment. Creation of regulatory labels would benefit further studies establishing a standardized dosing, safety, efficacy, and toxicity profile. Additionally, further studies elucidating the specific ginsenosides responsible for hair growth promotion and their associated mechanisms of action are needed. Berries, rice bran, and Annurca apple were secondarily found to be the next most potent candidates, requiring further research studies to substantiate the current evidence regarding these foods as hair growth promoter. Further research to validate current conclusions would improve the totality of evidence on these four food items, supporting the probability of approving their associated health claims.

\section{CONCLUSION}

While future research is required to further elucidate the safety, efficacy, and mechanisms of action of these food ingredients in the prevention and treatment of hair loss, it is clear that the potential benefits of numerous bioactive compounds in hair growth promotion are promising. The applications of oral consumption or topical application of these hair growth-promoting foods or food ingredients are also multifold. Incorporating these foods into dietary and lifestyle patterns can be adopted as personal homemade remedies or clinical treatment regimens to treat conditions such as male and female pattern hair loss, androgenetic alopecia, and chemotherapy-induced alopecia. It is likely that they can be used either in conjunction with or independently from drugbased treatment methods. The natural-based origin of these bioactive compounds will potentially reduce the amount of side effects observed with synthetic treatments. Additional benefit of incorporating these foods into dietary and lifestyle patterns is their widespread beneficial effects on physiological health. As seen throughout, each compound possesses numerous other benefits beyond hair growth promotion, including antioxidant, anti-inflammatory, and cardioprotective activities. The ultimate goal for functional foods is not only focused on promoting hair growth but also on improving self-confidence, self-esteem, and self-image perceptions normally associated with hair loss conditions.

Future research should focus on investigating the safety and efficacy of these food ingredients, particularly ginseng, in clinical settings, as well as establish specific dosing regimens and address potential toxicity profiles. Additionally, biomarkers used to assess hair growth improvement should be clarified, along with relevant mechanisms of action.

List of abbreviations: Annurca Apple Polyphenolic Extract, AAE; Bcl-2-associated X protein, BAX; B-cell Lymphoma 2, BCL-2; Beta-sitosterol, SITOS; Calcitonin-gene Related Peptide, CGRP; Chemotherapy-induced Alopecia, CIA; Dihydrotestosterone, DHT; Female Pattern Hair Loss, FPHL; Food and Drug Administration, FDA; Hair Growth Peptide, HGP; Heat Shock Protein 47, HSP47; Insulin-like Growth Factor-1, IGF-1; Keratinocyte Growth Factor, KGF; Korean Red Ginseng, KRG; Linoleic Acid, LA; Low-density Lipoprotein, LDL; Male Pattern Hair Loss, MPHL; Pentose Phosphate Pathway, PPP; Raspberry Ketone, RK; Rice Bran Supercritical 
CO2 Extract, RB-SCE; Sonic Hedgehog, Shh; Transforming Growth Factor Beta, TGF- $\beta$; Tumor Necrosis Factor Alpha, TNF- $\alpha$; Vascular Endothelial Growth Factor, VEG-F

Competing Interests: The authors have no financial interests or any other conflicts of interest to disclose.

Authors' and Contributions: All authors contributed to this review.

Acknowledgements and Funding: No funding was received for this manuscript

\section{REFERENCES}

1. Lin RL, Garibyan L, Kimball AB, Drake LA: Systemic causes of hair loss. Annals of Medicine. 2016;48(6):393-402. DOI:10.1080/07853890.2016.1180426

2. Williamson D, Gonzalez M, Finlay AY: The effect of hair loss on quality of life. Journal of the European Academy of Dermatology and Venereology. 2001;15(2):137-139. DOI:10.1046/j.1468-3083.2001.00229.x

3. Hunt N, McHale S: The psychological impact of alopecia. BMJ. 2005;331(7522):951-953.

4. Finner AM: Nutrition and hair: deficiencies and supplements. Dermatol Clin. 2013;31(1):167-172. DOI:10.1016/j.det.2012.08.015

5. Ghanaat M. Types of hair loss and treatment options, including the novel low-level light therapy and its proposed mechanism. South Med J. 2010;103(9):917-921. DOI: 10.1097/SMJ.0b013e3181ebcf71

6. Gowda D, Premalatha V, Imtiyaz D: Prevalence of Nutritional Deficiencies in Hair Loss among Indian Participants: Results of a Cross-sectional Study. Int J Trichology. 2017;9(3):101-104. DOI:10.4103/ijt.ijt_48_16

7. Gur J, Mawuntu M, Martirosyan D: FFC's Advancement of Functional Food Definition. Functional Foods in Health and Disease. 2018;8(7):385-397-397. DOI:10.31989/ffhd.v8i7.531

8. Thompson JM, Mirza MA, Park MK, Qureshi AA, Cho E: The Role of Micronutrients in Alopecia Areata: A Review. Am J Clin Dermatol. 2017;18(5):663-679. DOI: $10.1007 /$ s40257-017-0285-X

9. Disorders of Hair Follicles and Related Disorders [http:/www. accessmedicine.mhmedical.com/content.aspx?aid=1140788082] Accessed March 29, 2019

10. Breitkopf T, Leung G, Yu M, Wang E, McElwee KJ: The Basic Science of Hair Biology: What Are the Causal Mechanisms for the Disordered Hair Follicle? Dermatologic Clinics. 2013;31(1):1-19. DOI: 10.1016/j.det.2012.08.006

11. Phillips TG, Slomiany WP, Allison R: Hair Loss: Common Causes and Treatment. Am Fam Physician. 2017a;96(6):371-378.

12. Phillips TG, Slomiany WP, Allison R: Hair Loss: Common Causes and Treatment. AFP. 2017b;96(6):371-378.

13. Skin - Internal Medicine [http://www.accessmedicine.mhmedical.com/content. aspx?aid=1153306287] Accessed March 29, 2019 
14. Alopecia- Quick Medical Diagnosis \& Treatment 2019 [http://www.accessmedicine. mhmedical.com/content.aspx?aid=1159904327] Accessed March 29, 2019.

15. Mounsey AL, Reed SW: Diagnosing and Treating Hair Loss. AFP. 2009;80(4):356-362.

16. Banka N, Bunagan MJK, Shapiro J: Pattern hair loss in men: diagnosis and medical treatment. Dermatol Clin. 2013;31(1):129-140. DOI:10.1016/j.det.2012.08.003.

17. Herskovitz I, Tosti A. Female Pattern Hair Loss. Int J Endocrinol Metab. 2013;11(4). DOI:10.5812/ijem.9860

18. Kovacevic M, Goren A, Shapiro J, Sinclair R, Lonky NM, Situm M, Bulat V, Bolanca Z, McCoy J. Prevalence of hair shedding among women. Dermatologic Therapy. 2017;30(1):e12415. DOI:10.1111/dth.12415

19. Anatomy, Hair [http://europepmc.org/abstract/med/30020684] Accessed January 2, 2019.

20. Skin - Clinical Resource [http://www.accessmedicine.mhmedical.com/content.aspx? aid=1153306287] Accessed March 29, 2019.

21. Lourith N, Kanlayavattanakul M: Hair loss and herbs for treatment. Journal of Cosmetic Dermatology. 2013;12(3):210-222. DOI:10.1111/jocd.12051

22. Parsley WM, Perez-Meza D: Review of Factors Affecting the Growth and Survival of Follicular Grafts. J Cutan Aesthet Surg. 2010;3(2):69-75. DOI:10.4103/0974-2077.69014

23. Zia-Ul-Haq M, Riaz M, De Feo V, Jaafar HZE, Moga M. Rubus Fruticosus L: Constituents, Biological Activities and Health Related Uses. Molecules. 2014;19(8):10998-11029. DOI:10.3390/molecules190810998

24. Verma R, Gangrade T, Punasiya R, Ghulaxe C: Rubus fruticosus (blackberry) use as an herbal medicine. Pharmacogn Rev. 2014;8(16):101-104. DOI:10.4103/0973-7847.134239

25. Kaume L, Howard LR, Devareddy L: The blackberry fruit: a review on its composition and chemistry, metabolism and bioavailability, and health benefits. J Agric Food Chem. 2012;60(23):5716-5727. DOI:10.1021/jf203318p

26. Zambrano A, Raybaudi-Massilia R, Arvelo F, Sojo F: Cytotoxic and antioxidant properties in vitro of functional beverages based on blackberry (Rubus glaucus Benth) and soursop (Annona muricata L) pulps. Functional Foods in Health and Disease. 2018;8(11):531-547547. DOI:10.31989/ffhd.v8i11.541

27. Wallace TC, Giusti MM. Anthocyanins1. Adv Nutr. 2015;6(5):620-622. DOI:10.3945/an.115.009233

28. Food Applications and Physiological Effects of Anthocyanins as Functional Food Ingredients [https://benthamopen.com/ABSTRACT/TOFSJ-4-7] Accessed January 16, 2019.

29. Cefali LC, Franco JG, Nicolini GF, Ataide JA, Mazzola PG. In vitro antioxidant activity and solar protection factor of blackberry and raspberry extracts in topical formulation. $J$ Cosmet Dermatol. December 2018. DOI:10.1111/jocd.12842

30. Matsumoto H, Inaba H, Kishi M, Tominaga S, Hirayama M, Tsuda T. Orally administered delphinidin 3-rutinoside and cyanidin 3-rutinoside are directly absorbed in rats and humans and appear in the blood as the intact forms. J Agric Food Chem. 2001;49(3):1546-1551.

31. Miyazawa T, Nakagawa K, Kudo M, Muraishi K, Someya K. Direct intestinal absorption of red fruit anthocyanins, cyanidin-3-glucoside and cyanidin-3,5-diglucoside, into rats and humans. J Agric Food Chem. 1999;47(3):1083-1091. 
32. Kay CD, Mazza GJ, Holub BJ. Anthocyanins exist in the circulation primarily as metabolites in adult men. $J$ Nutr. 2005;135(11):2582-2588. DOI:10.1093/jn/135.11.2582

33. Nielsen ILF, Dragsted LO, Ravn-Haren G, Freese R, Rasmussen SE: Absorption and excretion of black currant anthocyanins in humans and watanabe heritable hyperlipidemic rabbits. J Agric Food Chem. 2003;51(9):2813-2820. DOI:10.1021/jf025947u.

34. Qin Y, Xia M, Ma J, Hao Y, Liu J, Mou H, Cao L, et al.: Anthocyanin supplementation improves serum LDL- and HDL-cholesterol concentrations associated with the inhibition of cholesteryl ester transfer protein in dyslipidemic subjects. Am J Clin Nutr. 2009;90(3):485-492. DOI:10.3945/ajen.2009.27814

35. Levy Y, Glovinsky Y: The effect of anthocyanosides on night vision. Eye (Lond). 1998;12 ( Pt 6):967-969. DOI:10.1038/eye.1998.250

36. Jayaprakasam B, Vareed SK, Olson LK: Nair MG: Insulin secretion by bioactive anthocyanins and anthocyanidins present in fruits. J Agric Food Chem. 2005;53(1):28-31. DOI:10.1021/jf049018+

37. Dan K, Takada A, Kanaho Y, Kusumi Y, Banno H: Anti-aging effects of black raspberry extract on cataract, alopecia, skin whitening, and weight loss. Functional Foods in Health and Disease. 2018;8(1):17-34-34. DOI:10.31989/ffhd.v8i1.389

38. Maggi CA, Meli A. The sensory-efferent function of capsaicin-sensitive sensory neurons. Gen Pharmacol. 1988;19(1):1-43.

39. Harada N, Okajima K: Effect of topical application of capsaicin and its related compounds on dermal insulin-like growth factor-I levels in mice and on facial skin elasticity in humans. Growth Horm IGF Res. 2007;17(2):171-176. DOI:10.1016/j.ghir.2006.12.005

40. Harada N, Okajima K, Narimatsu N, Kurihara H, Nakagata N: Effect of topical application of raspberry ketone on dermal production of insulin-like growth factor-I in mice and on hair growth and skin elasticity in humans. Growth Horm IGF Res. 2008;18(4):335-344. DOI:10.1016/j.ghir.2008.01.005

41. Harel S, Higgins CA, Cerise JE, Dai Z, Chen JC, Clynes R, Christiano AM: Pharmacologic inhibition of JAK-STAT signaling promotes hair growth. Science Advances. 2015;1(9):e1500973. DOI:10.1126/sciadv.1500973

42. Martin H, Burgess EJ, Smith WA, McGhie TK, Cooney JM, Lunken RCM, De Guzman E, et al.: JAK2 and AMP-kinase inhibition in vitro by food extracts, fractions and purified phytochemicals. Food Funct. 2015;6(1):305-312. DOI:10.1039/c4fo00626g

43. Miranda A, Gomez-Gaete C, Mennickent S: Role of Mediterranean diet on the prevention of Alzheimer disease. Rev Med Chil. 2017;145(4):501-507. DOI:10.4067/S003498872017000400010

44. Reboredo-Rodriguez P, Figueiredo-Gonzalez M, Gonzalez-Barreiro C, Simal-Gandara J, Salvador MD, Cancho-Grande B, Fregapane G: State of the Art on Functional Virgin Olive Oils Enriched with Bioactive Compounds and Their Properties. Int J Mol Sci. 2017;18(3). DOI:10.3390/ijms18030668

45. Farinetti A, Zurlo V, Manenti A, Coppi F, Mattioli AV: Mediterranean diet and colorectal cancer: A systematic review. Nutrition. 2017;43-44:83-88. DOI:10.1016/j.nut.2017.06.008 
46. Dussaillant C, Echeverria G, Urquiaga I, Velasco N, Rigotti A: Current evidence on health benefits of the mediterranean diet. Rev Med Chil. 2016;144(8):1044-1052. DOI:10.4067/S0034-98872016000800012

47. Fortes C, Mastroeni S, Mannooranparampil T, Abeni D, Panebianco A: Mediterranean diet: fresh herbs and fresh vegetables decrease the risk of Androgenetic Alopecia in males. Arch Dermatol Res. 2018;310(1):71-76. DOI:10.1007/s00403-017-1799-z

48. Choi J-S, Jung SK, Jeon M-H, Moon J-N, Moon W-S, Ji Y-H, Choi IS, Wook Son S. Effects of Lycopersicon esculentum extract on hair growth and alopecia prevention. $J$ Cosmet Sci. 2013;64(6):429-443.

49. Cardile V, Frasca G, Rizza L, Rapisarda P, Bonina F: Antiinflammatory effects of a red orange extract in human keratinocytes treated with interferon-gamma and histamine. Phytotherapy Research. 2010;24(3):414-418. DOI:10.1002/ptr.2973

50. Sharif MK, Butt MS, Anjum FM, Khan SH: Rice bran: a novel functional ingredient. Crit Rev Food Sci Nutr. 2014;54(6):807-816. DOI:10.1080/10408398.2011.608586.

51. Sohail M, Rakha A, Butt MS, Iqbal MJ, Rashid S: Rice bran nutraceutics: A comprehensive review. Crit Rev Food Sci Nutr. 2017;57(17):3771-3780. DOI:10.1080/ 10408398.2016.1164120

52. S Vallabha V, Indira TN, Jyothi Lakshmi A, Radha C, Tiku PK: Enzymatic process of rice bran: a stabilized functional food with nutraceuticals and nutrients. J Food Sci Technol. 2015;52(12):8252-8259. DOI:10.1007/s13197-015-1926-9

53. Liu YQ, Strappe P, Shang WT, Zhou ZK: Functional peptides derived from rice bran proteins. Crit Rev Food Sci Nutr. September 2017:1-8. DOI:10.1080/ 10408398.2017.1374923

54. Manosroi A, Ruksiriwanich W, Abe M, Manosroi W, Manosroi J: Transfollicular enhancement of gel containing cationic niosomes loaded with unsaturated fatty acids in rice (Oryza sativa) bran semi-purified fraction. Eur J Pharm Biopharm. 2012;81(2):303313. DOI:10.1016/j.ejpb.2012.03.014

55. Choi J-S, Jeon M-H, Moon W-S, Moon J-N, Cheon EJ, Kim J-W, Jung SK, Ji Y-H, Son SW, Kim M-R: In vivo hair growth-promoting effect of rice bran extract prepared by supercritical carbon dioxide fluid. Biol Pharm Bull. 2014;37(1):44-53.

56. Danilenko DM, Ring BD, Pierce GF: Growth factors and cytokines in hair follicle development and cycling: recent insights from animal models and the potentials for clinical therapy. Mol Med Today. 1996;2(11):460-467.

57. Fujie T, Katoh S, Oura H, Urano Y, Arase S: The chemotactic effect of a dermal papilla cell-derived factor on outer root sheath cells. Journal of Dermatological Science. 2001;25(3):206-212. DOI:10.1016/S0923-1811(00)00130-4

58. Choi J-S, Park JB, Moon W-S, Moon J-N, Son SW, Kim M-R: Safety and Efficacy of Rice Bran Supercritical CO2 Extract for Hair Growth in Androgenic Alopecia: A 16-Week Double-Blind Randomized Controlled Trial. Biol Pharm Bull. 2015;38(12):1856-1863. DOI:10.1248/bpb.b15-00387

59. Kim JS: Investigation of Phenolic, Flavonoid, and Vitamin Contents in Different Parts of Korean Ginseng (Panax ginseng C.A. Meyer). Prev Nutr Food Sci. 2016;21(3):263-270. DOI:10.3746/pnf.2016.21.3.263 
60. Patel S, Rauf A: Adaptogenic herb ginseng (Panax) as medical food: Status quo and future prospects. Biomed Pharmacother. 2017;85:120-127. DOI:10.1016/j.biopha.2016.11.112

61. Park S, Shin W-S, Ho J: Fructus panax ginseng extract promotes hair regeneration in C57BL/6 mice. J Ethnopharmacol. 2011;138(2):340-344. DOI:10.1016/j.jep.2011.08.013.

62. Park G-H, Park K, Cho H, Lee S-M, Han JS, Won CH, Chang SE, et al.: Lee DH. Red ginseng extract promotes the hair growth in cultured human hair follicles. J Med Food. 2015;18(3):354-362. DOI:10.1089/jmf.2013.3031.

63. Keum DI, Pi L-Q, Hwang ST, Lee W-S: Protective effect of Korean Red Ginseng against chemotherapeutic drug-induced premature catagen development assessed with human hair follicle organ culture model. $J$ Ginseng Res. 2016;40(2):169-175. DOI:10.1016/j.jgr.2015.07.004

64. Lee Y, Kim SN, Hong YD, Park BC, Na Y: Panax ginseng extract antagonizes the effect of DKK-1-induced catagen-like changes of hair follicles. Int J Mol Med. 2017;40(4):11941200. DOI:10.3892/ijmm.2017.3107

65. Murata K, Takeshita F, Samukawa K, Tani T, Matsuda H: Effects of ginseng rhizome and ginsenoside Ro on testosterone $5 \alpha$-reductase and hair re-growth in testosterone-treated mice. Phytother Res. 2012;26(1):48-53. DOI:10.1002/ptr.3511

66. Li Z, Li J-J, Gu L-J, Zhang D-L, Wang Y-B, Sung C-K: Ginsenosides Rbı and Rd regulate proliferation of mature keratinocytes through induction of p63 expression in hair follicles. Phytother Res. 2013;27(7):1095-1101. DOI:10.1002/ptr.4828

67. Truong V-L, Bak MJ, Lee C, Jun M, Jeong W-S: Hair Regenerative Mechanisms of Red Ginseng Oil and Its Major Components in the Testosterone-Induced Delay of Anagen Entry in C57BL/6 Mice. Molecules. 2017;22(9). DOI:10.3390/molecules22091505

68. Begum S, Lee MR, Gu LJ, Hossain MJ, Kim HK, Sung CK: Comparative hair restorer efficacy of medicinal herb on nude (Foxn1nu) mice. Biomed Res Int. 2014;2014:319795. DOI: $10.1155 / 2014 / 319795$

69. Oh GN, Son SW: Efficacy of korean red ginseng in the treatment of alopecia areata. $J$ Ginseng Res. 2012;36(4):391-395. DOI:10.5142/jgr.2012.36.4.391

70. Ryu HJ, Yoo MG, Son SW: The efficacy of 3\% minoxidil vs. combined 3\% minoxidil and Korean red ginseng in treating female pattern alopecia. Int J Dermatol. 2014;53(6):e340342. DOI:10.1111/ijd.12359

71. Kim SN, Kim S, Hong YD, Park H, Shin SH, Kim AR, Park BC, et al.: The ginsenosides of Panax ginseng promote hair growth via similar mechanism of minoxidil. J Dermatol Sci. 2015;77(2):132-134. DOI:10.1016/j.jdermsci.2014.12.007

72. Shin DH, Cha YJ, Yang KE, Jang I-S, Son C-G, Kim BH, Kim JM. Ginsenoside Rg3 upregulates the expression of vascular endothelial growth factor in human dermal papilla cells and mouse hair follicles. Phytother Res. 2014;28(7):1088-1095. doi:10.1002/ptr.5101.

73. Li Z, Ryu S-W, Lee J, Choi K, Kim S, Choi C: Protopanaxatirol type ginsenoside Re promotes cyclic growth of hair follicles via inhibiting transforming growth factor $\beta$ signaling cascades. Biochem Biophys Res Commun. 2016;470(4):924-929. DOI:10.1016/j.bbrc.2016.01.148

74. Suzuki A, Matsuura D, Kanatani H, Yano S, Tsunakawa M, Matsuyama S, Shigemori H: Inhibitory Effects of Polyacetylene Compounds from Panax ginseng on Neurotrophin 
Receptor-Mediated Hair Growth. Biol Pharm Bull. 2017;40(10):1784-1788. DOI:10.1248/bpb.b17-00205

75. Tenore GC, Caruso D, Buonomo G, D’Urso E, D'Avino M, Campiglia P, Marinelli L,et al.: Annurca (Malus pumila Miller cv. Annurca) apple as a functional food for the contribution to a healthy balance of plasma cholesterol levels: results of a randomized clinical trial. J Sci Food Agric. 2017;97(7):2107-2115. DOI:10.1002/jsfa.8016.

76. D'Angelo S, Martino E, Ilisso CP, Bagarolo ML, Porcelli M, Cacciapuoti G: Pro-oxidant and pro-apoptotic activity of polyphenol extract from Annurca apple and its underlying mechanisms in human breast cancer cells. Int $J$ Oncol. 2017;51(3):939-948. DOI:10.3892/ijo.2017.4088.

77. Stirpe M, Palermo V, Bianchi MM, Silvestri R, Falcone C, Tenore G, Novellino E, et al.: Annurca apple (M. pumila Miller cv Annurca) extracts act against stress and ageing in S. cerevisiae yeast cells. BMC Complement Altern Med. 2017;17(1):200. DOI:10.1186/s12906-017-1666-7

78. Riccio G, Sommella E, Badolati N, Salviati E, Bottone S, Campiglia P, Dentice M, et al.: Annurca Apple Polyphenols Protect Murine Hair Follicles from Taxane Induced Dystrophy and Hijacks Polyunsaturated Fatty Acid Metabolism toward $\beta$-Oxidation. Nutrients. 2018;10(11). DOI:10.3390/nu10111808

79. Tenore GC, Caruso D, Buonomo G, D'Avino M, Santamaria R, Irace C, Piccolo M, et al.: Annurca Apple Nutraceutical Formulation Enhances Keratin Expression in a Human Model of Skin and Promotes Hair Growth and Tropism in a Randomized Clinical Trial. $J$ Med Food. 2018;21(1):90-103. DOI:10.1089/jmf.2017.0016

80. Kim KH, Moon E, Kim SY, Choi SU, Son MW, Choi SZ, Lee KR: Bioactive sesquiterpenes from the essential oil of Thuja orientalis. Planta Med. 2013;79(17):16801684. DOI:10.1055/s-0033-1350952

81. Ojeswi BK, Khoobchandani M, Hazra DK, Srivastava MM: Protective effect of Thuja occidentalis against DMBA-induced breast cancer with reference to oxidative stress. Hum Exp Toxicol. 2010;29(5):369-375. DOI:10.1177/0960327110364150

82. Torres A, Vargas Y, Uribe D, Carrasco C, Torres C, Rocha R, Oyarzun C, et al.: Proapoptotic and anti-angiogenic properties of the $\alpha / \beta$-thujone fraction from Thuja occidentalis on glioblastoma cells. J Neurooncol. 2016;128(1):9-19. DOI:10.1007/s11060016-2076-2

83. R EB, Jesubatham PD, V M BG, S V, S S: Non-toxic and non teratogenic extract of Thuja orientalis L. inhibited angiogenesis in zebra fish and suppressed the growth of human lung cancer cell line. Biomed Pharmacother. 2018;106:699-706. DOI:10.1016/j.biopha.2018.07.010

84. Remya V, Kuttan G: Homeopathic remedies with antineoplastic properties have immunomodulatory effects in experimental animals. Homeopathy. 2015;104(3):211-219. DOI:10.1016/j.homp.2014.11.004

85. Kupeli Akkol E, Ilhan M, Ayse Demirel M, Keleş H, Tumen I, Suntar I: Thuja occidentalis L. and its active compound, $\alpha$-thujone: Promising effects in the treatment of polycystic ovary syndrome without inducing osteoporosis. J Ethnopharmacol. 2015;168:25-30. DOI:10.1016/j.jep.2015.03.029 
86. Won J-N, Lee S-Y, Song D, Poo H: Antiviral activity of the plant extracts from Thuja orientalis, Aster spathulifolius, and Pinus thunbergii against influenza virus $\mathrm{A} / \mathrm{PR} / 8 / 34$. $J$ Microbiol Biotechnol. 2013;23(1):125-130.

87. Alamdari DH, Aghasizadeh-Sharbaf M, Mohadjerani M, Ferns GA, Avan A: ProoxidantAntioxidant Balance and Antioxidant Properties of Thuja orientalis L: A Potential Therapeutic Approach for Diabetes Mellitus. Curr Mol Pharmacol. 2018;11(2):109-112. DOI: $10.2174 / 1874467210666170404112211$

88. Shin I-S, Shin N-R, Jeon C-M, Kwon O-K, Hong J-M, Kim H-S, Oh S-R, et al.: Thuja orientalis reduces airway inflammation in ovalbumin-induced allergic asthma. Mol Med Rep. 2015;12(3):4640-4646. DOI:10.3892/mmr.2015.3910

89. Kim T-H, Li H, Wu Q, Lee HJ, Ryu J-H: A new labdane diterpenoid with antiinflammatory activity from Thuja orientalis. J Ethnopharmacol. 2013;146(3):760-767. DOI:10.1016/j.jep.2013.02.001

90. Silva IS, Nicolau LAD, Sousa FBM, Araújo S De, Oliveira AP, Araújo TSL, Souza LKM, et al.: Evaluation of anti-inflammatory potential of aqueous extract and polysaccharide fraction of Thuja occidentalis Linn. in mice. Int J Biol Macromol. 2017;105(Pt 1):11051116. DOI:10.1016/j.ijbiomac.2017.07.142

91. Zhang N, Park DK, Park H-J: Hair growth-promoting activity of hot water extract of Thuja orientalis. BMC Complement Altern Med. 2013;13:9. DOI:10.1186/1472-6882-13-9

92. Suleria HAR, Osborne S, Masci P, Gobe G: Marine-Based Nutraceuticals: An Innovative Trend in the Food and Supplement Industries. Mar Drugs. 2015;13(10):6336-6351. DOI: $10.3390 / \mathrm{md} 13106336$

93. Wells ML, Potin P, Craigie JS, Raven JA, Merchant SS, Helliwell KE, Smith AG, et al.: Algae as nutritional and functional food sources: revisiting our understanding. $J$ Appl Phycol. 2017;29(2):949-982. DOI:10.1007/s10811-016-0974-5

94. De Luca C, Mikhal'chik EV, Suprun MV, Papacharalambous M, Truhanov AI, Korkina LG: Skin Antiageing and Systemic Redox Effects of Supplementation with Marine Collagen Peptides and Plant-Derived Antioxidants: A Single-Blind Case-Control Clinical Study. Oxid Med Cell Longev. 2016;2016. DOI:10.1155/2016/4389410

95. Kang J-I, Kim M-K, Lee J-H, Jeon Y-J, Hwang E-K, Koh Y-S, Hyun J-W, et al.: Undariopsis peterseniana Promotes Hair Growth by the Activation of Wnt/ $\beta$-Catenin and ERK Pathways. Mar Drugs. 2017;15(5). DOI:10.3390/md15050130

96. Ablon G: A 6-month, randomized, double-blind, placebo-controlled study evaluating the ability of a marine complex supplement to promote hair growth in men with thinning hair. J Cosmet Dermatol. 2016;15(4):358-366. DOI:10.1111/jocd.12265

97. Hornfeldt CS: Growing evidence of the beneficial effects of a marine protein-based dietary supplement for treating hair loss. $J$ Cosmet Dermatol. 2018;17(2):209-213. DOI:10.1111/jocd.12400

98. Hornfeldt CS, Holland M, Bucay VW, Roberts WE, Waldorf HA, Dayan SH: The Safety and Efficacy of a Sustainable Marine Extract for the Treatment of Thinning Hair: A Summary of New Clinical Research and Results from a Panel Discussion on the Problem of Thinning Hair and Current Treatments. J Drugs Dermatol. 2015;14(9):s15-22. 
99. Anton M, Nau F, Nys Y: Bioactive egg components and their potential uses. World's Poultry Science Journal. 2006;62(3):429-438. DOI:10.1017/S004393390600105X.

100. Yoshikawa M: Bioactive peptides derived from natural proteins with respect to diversity of their receptors and physiological effects. Peptides. 2015;72:208-225. DOI:10.1016/j.peptides.2015.07.013

101. Eilat-Adar S, Sinai T, Yosefy C, Henkin Y: Nutritional Recommendations for Cardiovascular Disease Prevention. Nutrients. 2013;5(9):3646-3683. DOI:10.3390/nu5093646

102. Nakamura T, Yamamura H, Park K, Pereira C, Uchida Y, Horie N, Kim M, et al.: Naturally Occurring Hair Growth Peptide: Water-Soluble Chicken Egg Yolk Peptides Stimulate Hair Growth Through Induction of Vascular Endothelial Growth Factor Production. J Med Food. 2018;21(7):701-708. DOI:10.1089/jmf.2017.4101

103. Ajibola A: Physico-Chemical and Physiological Values of Honey and Its Importance as a Functional Food. International Journal of Food and Nutritional Science. 2015;2(2):180-188.

104. Luchese RH, Prudencio ER, Guerra AF: Honey as a Functional Food. Honey Analysis. March 2017. DOI:10.5772/67020

105. Oses SM, Pascual-Mate A, Fernandez-Muino MA, Lopez-DIaz TM, Sancho MT: Bioactive properties of honey with propolis. Food Chem. 2016;196:1215-1223. DOI:10.1016/j.foodchem.2015.10.050

106. Burlando B, Cornara L: Honey in dermatology and skin care: a review. J Cosmet Dermatol. 2013;12(4):306-313. DOI:10.1111/jocd.12058

107. Eady EA, Layton AM, Cove JH: A honey trap for the treatment of acne: manipulating the follicular microenvironment to control Propionibacterium acnes. Biomed Res Int. 2013;2013:679680. DOI:10.1155/2013/679680

108. Martirosyan DM, Singh J: A new definition of functional food by FFC: what makes a new definition unique? Functional Foods in Health and Disease. 2015;5(6):209-223-223. DOI:10.31989/ffhd.v5i6.183

109.Zong J, Martirosyan DM: Anticancer effects of garlic and garlic-derived bioactive compounds and its potential status as functional food. Bioactive Compounds in Health and Disease. 2018;1(2):16-35-35.

110. Hair loss- American Academy of Dermatology [https://www.aad.org/public/ diseases/hair-and-scalp-problems/hair-loss] Accessed March 29, 2019. 